\title{
The curious absence of human rights: Can the WIPO Development Agenda transform intellectual property negotiation?
}

\author{
AMANDA BARRATT \\ Lecturer, Department of Private Law, University of Cape Town
}

\begin{abstract}
"The terrible situations affecting many states and peoples around the world should be a key element that mobilizes the discussions in this forum ... it is unfortunate we could not see a little more flexibility or humanity in these discussions and make IP a constructive tool."
\end{abstract}

Delegate from Ecuador at the WIPO Development Agenda discussions, 29 June 2006. ${ }^{1}$

\section{INTRODUCTION}

International intellectual property (IP) treaties are under constant negotiation. Essentially, the debates are about one thing: levels of IP protection. Clear battle-lines have emerged: developed states (exporters of patented and copyrighted material) favour international treaties which compel states to adopt certain minimum IP protection levels in their domestic laws. Developing countries (net importers of protected products) require more flexible international IP standards in order to shape their domestic rules to suit local circumstances and needs. ${ }^{2}$

In these negotiations, developing countries have based their positions on fundamental principles internal to intellectual property law. They have emphasised that protection of intellectual property should promote public welfare and the public interest and that it is necessary to achieve a balance between the rights of patent and copyright holders and the broader social good. These arguments can be labelled "balance and welfareenhancing narratives". ${ }^{3}$

However, the internal principles of the IP system define neither "public welfare" nor "the public interest" and provide no bottom lines with which to assess whether the balance struck between the public good and the private rights of patent and copyright

\footnotetext{
1 "Blogging WIPO: Development Agenda blocked" (June 29, 2006). Available at the Electronic Frontier Foundation web page at http://www.eff.org/deeplinks/archive/2006/06 (last visited August 2010).

${ }^{2}$ For a general overview of the history of such negotiations see Peter Drahos "Developing countries and international intellectual property standard-setting" (2002) 5 Journal of World Intellectual Property 765.

${ }^{3}$ Cf Ruth Okediji "Narratives of developing country participation in the global intellectual property system" (2003) 7 Singapore Journal of International and Comparative Law 315.
} 
holders is reasonable or legally acceptable. Repeated reliance on these principles has exposed the inherent weaknesses of internal "balance and welfare-enhancing arguments" - developed states can rely on the same internal balance and welfareenhancing principles to promote very different agendas. ${ }^{4}$

Outside of WIPO, United Nations human rights experts have used binding human rights documents, particularly the International Covenant on Economic, Social and Cultural Rights (ICESCR), ${ }^{5}$ to develop clear benchmarks against which the human rights impact of intellectual property rules may be measured. ${ }^{6}$ These benchmarks could also be used to measure the extent to which intellectual property rules promote the public good and actually achieve a balance between the rights of patent holders and the broader public interest.

Recently, developing countries have celebrated the adoption of the 2007 WIPO Development Agenda as a "paradigm shift" in international IP negotiation. ${ }^{7}$ But the Development Agenda contains no clear additional benchmarks to direct future discussion beyond the impasse evident in previous talks. This article suggests that developing country negotiators should use human rights standards and benchmarks to move the Development Agenda forward and ensure a more meaningful "paradigm shift" in international IP negotiation.

To illustrate the weakness of internal arguments and the potential value of human rights benchmarks, the article examines aspects of international norm-setting and negotiation as played out in previous IP negotiations: first at the World Trade Organisation (WTO) Doha Ministerial Meetings on TRIPS ${ }^{8}$ and Public Health in 2001 and 2003, and then at the World Intellectual Property Organisation (WIPO) during the WIPO Development Agenda discussions from 2005 to 2007. It also examines the shortcomings of the new WIPO Development Agenda and argues that a focus on human rights obligations could improve and give clearer direction to "development-orientated normsetting" in future. To illustrate this discussion, the paper focuses on patents and essential medicines.

\footnotetext{
${ }^{4}$ This is explored in the discussion below.

${ }^{5}$ International Covenant on Economic, Social and Cultural Rights (1967) 6 ILM 360.

${ }^{6}$ See particularly United Nations Committee on Economic, Social and Cultural Rights (CESCR) General comment 14: The right to the highest attainable standard of health (Article 12) (UN Doc E/C.12/2000/4) and the reports of UN Special Rapporteur Paul Hunt The right of everyone to the enjoyment of the highest attainable standard of physical and mental health: report of the Special Rapporteur (UN Doc E/CN.4/2004/49/Add.1 (2004), UN Special Rapporteur Anand Grover The right of everyone to the enjoyment of the highest attainable standard of physical and mental health: report of the Special Rapporteur (A/HRC/11/12 (2009)) and UN High Commissioner Simon Walker The Impact of the Agreement on TradeRelated Aspects of Intellectual Property Rights on Human Rights: Report of the High Commissioner, ECOSOC (Commission on Human Rights, Sub-Commission on the Promotion and Protection of Human Rights, 52 nd Session, Provisional Agenda item 4. UN Doc E/CN.4/Sub.2/2001/13 (2001) (27 July 2001).

${ }^{7}$ Statement by Egypt on behalf of the Development Action Group, presented at the $5^{\text {th }}$ Session of the CDIP, 26-30 April, 2010.

8 Agreement on Trade-Related Aspects of Intellectual Property Rights, Including Trade in Counterfeit Goods, adopted Dec 151993 (1994) 33 ILM 81. Doha is the capital city of Qatar.
} 


\section{THE DOHA DISCUSSIONS: THE LIMITATIONS OF INTERNAL ARGUMENTS}

The Doha Ministerial Meetings of the WTO in 2001 and 2003 provide an excellent illustration of the use of "internal arguments" and the difficulties inherent in this approach. The central controversy at Doha was compulsory licensing, and particularly the legality of exporting generic drugs manufactured under such licences. At the Doha Meetings developing countries presented an internal "balance and welfare-enhancing" argument based on public health interests.

\subsection{Background to the discussions}

The patent system is based on monopolies giving the patent holder exclusive rights to manufacture patented products, use patented processes or license others to do so. ${ }^{9}$ Because patent monopolies exclude market competition, patented products can be sold at supra-competitive prices. ${ }^{10}$ In general, states do not favour monopolies that result in uncompetitive pricing practices but, historically, governments have sanctioned patent monopolies on the grounds that they encourage development of "important inventions" which benefit society. ${ }^{11}$ Indeed, this remains the core justification for patent monopolies, and "there is virtually unanimous agreement that the purpose of the patent system is to promote innovation by granting exclusive rights to encourage invention".12

One obvious social cost of patent monopolies is that some people are unable to pay monopoly prices. ${ }^{13}$ It has been long recognised that the expected public benefits of innovation will be undermined if patent monopolies result in excessive pricing, making new products unaffordable. ${ }^{14}$ Thus another foundational premise of the patent system is the need for an appropriate balance between patent monopolies given as incentives to innovators and the ability of the public to use and benefit from new inventions. ${ }^{15}$

\footnotetext{
${ }_{9}^{9}$ David Bainbridge Intellectual property 4 ed Pearson Education (1999) at 317.

10 Daniel Gifford "How do the social benefits and costs of the patent system stack up in pharmaceuticals?" (2004) 12 Journal of Intellectual Property Law 75 at 102.

11 Robert Merges \& Jane Ginsburg Foundations of intellectual property Foundation Press (2004) at 21; Brad Sherman \& Lionel Bently Making of modern intellectual property law Cambridge University Press (1999) at 129-134. See also Drahos Death of patents Lawtext Publishing and Queen Mary Intellectual Property Research Institute (2005) at 1-2 discussing this and other historical policy objectives.

12 Dan L Burk \& Mark Lemley "Policy levers in patent law" (2003) 89 Virginia Law Review 1575 at 1580 ; WR Cornish Intellectual property: patents, copyrights, trade marks and allied rights 4 ed Sweet \& Maxwell (1999) at 129. Barton argues that "[a] patent monopoly is justified only if the monopoly is likely to lead to genuine incentives for research and for bringing new products to market": see John Barton "Issues posed by a world patent system" in Maskus \& Reichman (eds) International public goods and transfer of technology under a globalized intellectual property regime Cambridge University Press (2005) 617 at 623.

13 Merges \& Nelson describe this as the "underuse of the invention due to patent monopolies". See Robert Merges \& Richard Nelson "On the complex economics of patent scope" (1990) 90 Columbia Law Review 839 at 868. See also William Landes \& Richard Posner The economic structure of intellectual property law Harvard University Press (2003) at 310.

${ }^{14}$ See the historical overview by Fritz Machlup \& Edith Penrose "The patent controversy in the nineteenth century" (1950) 10 Journal of Economic History 1-29.

15 Burk \& Lemley (fn 12 above) at 1575; Louis Kaplow "The patent-antitrust intersection: a reappraisal" (1984) 97 Harvard Law Review 1813 at 1834. See also Kenneth Arrow "Economic welfare and the
} 
"Balance and welfare-enhancing" arguments rely on these foundational principles and hold intellectual property law to its own premises and legitimising justifications.

In principle, because patent monopolies are government grants, governments can decide when to award them and the terms on which they are awarded. ${ }^{16}$ Government might decide that the social costs of monopoly protection are unacceptable in certain situations and might therefore exclude certain products or process from the patent system. Governments can also limit the scope of patent protection. No patent is absolute and all states make some provision for compulsory licensing. ${ }^{17}$ Compulsory licences permit government agencies (or private companies authorised by the government) to manufacture generic equivalents of patented products without the consent of the patentholder. $^{18}$

The TRIPS Agreement was designed to strengthen international protection of intellectual property by raising compulsory local protection levels and thus restricting states' domestic IP policy options. ${ }^{19}$ A good example is the protection required for pharmaceuticals. Before TRIPS, states had the policy freedom to decide what to patent and on what terms. Many states excluded pharmaceuticals from patent protection on the ground that it was not in the public interest to increase the price of medicines through patent monopolies. ${ }^{20}$ Many states protected only processes, making it permissible to produce generic equivalents of patented products (including pharmaceuticals) by reverse engineering. ${ }^{21}$ India's extensive generic manufacturing industry was based on this kind of patent system. ${ }^{22}$

Restricting this policy freedom was a primary objective for developed states during the TRIPS negotiations. They complained that the global standards at that time were "inadequate" and proposed raising the minimum protection standards required in all

allocation of resources for invention" in Rosenberg (ed) The economics of technological change Penguin (1971) at 172-173.

16 Bainbridge (fn 9 above) at 324.

17 World Health Organization. Commission on Intellectual Property Rights, Innovation and Public Health Public health, innovation, and intellectual property rights: report of the Commission on Intellectual Property Rights, Innovation and Public Health World Health Organization (2006). Available at http://www.who.int/intellectualproperty/documents/thereport/en/ (last visited August 2010) at 5455; UNCTAD-ICTSD Resource book on TRIPS and development Cambridge University Press (2005) at 468; Developing Country Group's paper submitted at the WTO Ministerial Meeting on TRIPS and Public Health (29 June 2001) IP/C/W/296 para 29.

18 Carlos Correa "Patent rights' provisions" in Correa \& Yusuf (eds) Intellectual property and international trade: the TRIPS Agreement. 2 ed Wolters-Kluwer (2008) 227 at 245; UNCTAD-ICTSD (fn 17 above) at 461; Bainbridge (fn 9 above) at 392ff.

${ }^{19}$ See generally the discussions in Peter Drahos with John Braithwaite Information feudalism: who owns the knowledge economy? Earthscan (2002); Susan Sell Private power, public law: the globalization of intellectual property rights Cambridge University Press (2003) and Keith Maskus \& Jerome H Reichman (eds) International public goods and transfer of technology under a globalized intellectual property regime Cambridge University Press (2005).

${ }^{20}$ A 1988 WIPO study of the Paris Convention members found that 49 of the 98 members did not grant pharmaceutical patents. See Drahos (fn 11 above) at 3.

${ }^{21}$ Drahos \& Braithwaite (fn 19 above) at 59.

22 Srividhya Ragavan "Of the inequals of the Uruguay Round" (2006) 10 Marquette Intellectual Property Law Review 273 at 289-290; Drahos (fn 2 above) at 768. 
states' domestic IP systems. ${ }^{23}$ TRIPS now obliges member states to provide patent protection for almost all inventions, including medicines, ${ }^{24}$ and mandates patent protection for products as well as processes. ${ }^{25}$

TRIPS also restricts the circumstances under which states can issue compulsory licences for patented products. TRIPS Article 31 does provide for compulsory licensing (and is therefore classified as a "flexibility clause") ${ }^{26}$ but Article 31 requirements are very complicated, cumbersome and circumscribed, permitting far less domestic flexibility than was possible before TRIPS. Article 31(f) particularly impeded the availability of generic medicines, ${ }^{27}$ providing that compulsory licences should be "authorized predominantly for the supply of the domestic market of the Member authorizing such use". ${ }^{28}$ Most developing states do not have the infrastructure to manufacture generic drugs for themselves. ${ }^{29}$ Article 31(f) placed severe limitations on their ability to import generic drugs because states could import only from countries that manufactured such drugs primarily for their domestic markets.

By the time the Doha talks began in 2001, the international patent system had made it increasingly difficult for states to control availability of affordable essential medicines required to combat the HIV/AIDS pandemic. At that time on-patent prices of antiretroviral treatment ranged from US\$10 000 to US\$15 000 per patient per year. ${ }^{30}$ Generic equivalents cost a fraction of the price - Indian generics manufacturer Cipla, for example, could offer treatment packages for a mere US\$350 per year. ${ }^{31}$ In this context the patents on antiretroviral drugs created a publicity disaster for patent-holding companies. The headlines were emphatic: "Patent Greed" in London's Daily Telegraph; ${ }^{32}$ "Protection Racket" in the New Scientist; ${ }^{33}$ "The Profits that Kill" in New African. ${ }^{34}$ One response by patent holders was to offer heavily discounted drugs to poor countries. ${ }^{35}$

${ }^{23}$ See United States proposal at the GATT meeting: Suggestion by the United States for achieving the negotiating objective MTN.GNG/NG11/W/14 October 1987 at 3, and the sources cited in fn 19 above.

${ }^{24}$ TRIPS Art 27(1); Jayashree Watal Intellectual property rights in the WTO and developing countries Kluwer Law International (2001) at 4.

${ }^{25}$ Art 27(1).

26 TRIPS is largely a protectionist treaty. Clauses which limit owners' rights are thus "exceptions" to the broad rights given to patent holders.

${ }^{27}$ As originally worded. See the discussion on "Paragraph 6 Agreement" below.

28 TRIPS Article 31(f).

${ }^{29}$ Amit Gupta "Patent rights on pharmaceutical products and affordable drugs: can TRIPS provide a solution?" (2004) 2 Buffalo Intellectual Property Law Journal 127 at 138.

30 Médecins sans Frontières Untangling the web of price reductions: a pricing guide for the purchase of ARVs for developing countries 11 ed Médecins sans Frontières (2008) at 6, noting the lowest-available onpatent price (for standard first-line triple therapy) of US $\$ 10439$ per year in January 2000.

31 Prices quoted by Mac Margolis et al "An AIDS-drug price war" Newsweek 19 February 2001.

32 Helen Brown "Patent greed" Daily Telegraph 21 April 2001.

33 Debora MacKenzie "Protection racket" New Scientist 21 July 2001.

34 Osei Boateng "The profits that kill” (2001) 22 New African 30 April 2001.

35 Mark Heywood "Drug access, patents and global health: 'chaffed and waxed sufficient"” (2002) 23 Third World Quarterly 217 at 227. See also the price tables published in annual volumes of Médecins sans Frontières Untangling the web (fn 30 above). 
Developing states, however, have found it extremely difficult to plan their public health programmes around pharmaceutical companies' discount schemes. The schemes depend largely on business decisions of patent-holding companies and are far from guaranteed: states cannot rely on either sources or prices and have very little control over which medicines are discounted, for how long or in what volume. ${ }^{36}$ Not all onpatent drugs are included in the schemes, and this reduces states' public health options for providing the most appropriate medicines. ${ }^{37}$ Some of the most effective and most easily dispensed fixed-dose combinations are manufactured only by genericsproducers. ${ }^{38}$ These factors impede planning and development of HIV/AIDS programmes.

Developing states need more control over the supply of essential medicines. They want the IP policy space to manufacture or import generic drugs. ${ }^{39}$ This would enable them to plan and execute their public health programmes more effectively. This would furthermore give them a reliable and predictable source of medicines, a wider choice of drugs and suppliers, and the ability to enter into long-term contracts. ${ }^{40}$ Developing states are also concerned that discount schemes might be curtailed or abandoned if generic competition is eliminated. ${ }^{41}$

\subsection{Internal arguments at Doha}

The Doha discussions on TRIPS and Public Health were initiated by the African Group early in 2001. Those states, together with other developing countries, were concerned about the effects of TRIPS on access to essential medicines, particularly those needed to

${ }^{36}$ United Kingdom, Department for International Development Increasing people's access to essential medicines in developing countries: a framework for good practice in the pharmaceutical industry DFID (2005) at 32.

${ }^{37}$ See the drugs tables in Médecins sans Frontières (fn 30 above).

${ }^{38} \mathrm{See}$, for example, the drugs tables in Médecins sans Frontières (fn 30 above).

39 WTO.TRIPS Council. Minutes of special discussion on intellectual property and access to medicines, June 18-22, 2001 [IP/C/M/31] Brazilian Delegation IP/C/M/31 at 11; Argentinian Delegation IP/C/M/31 at 13.

${ }^{40}$ See the discussion of these and other benefits of compulsory licensing in Commission on Intellectual Property Rights Integrating Intellectual Property Rights and Development Policy: Report of the Commission on Intellectual Property Rights United Kingdom. Commission on Intellectual Property Rights (2002). Available at http:/ /www.iprcommission.org (last visited August 2010) at 42-45.

${ }^{41}$ One of the strongest arguments for compulsory licensing is the effect that this has on the price of brand-name drugs. Differential pricing schemes instituted by the originator companies are partly a response to competition in the market-place, and it is unlikely that prices would have dropped as significantly without generic competition (Wesley Cann "On the relationship between intellectual property rights and the need of less-developed countries for access to pharmaceuticals: creating a legal duty to supply under a theory of progressive global constitutionalism" (2004) 25 University of Pennsylvania Journal of International Economic Law 755 at 804; CIPR (fn 40 above) at 35). See Landes \& Posner (fn 13 above) at 313-314 for discussion on the effect of generic competition on originator prices. A predictable market also favours generics producers, since they are able to forecast probable sales and can feel reasonably confident about their production investments (World Health Organization "Access to medicines" (2005) 19 WHO Drug Information 236 at 238; Jayashree Watal "Background note for the Workshop on Differential Pricing and Financing of Essential Drugs". Available at http://www.wto.org/english/tratop e/trips e/wto background e.doc (last visited August 2010) at 6). 
combat HIV/AIDS. ${ }^{42}$ This initiative was partly a response to attempts by the United States and pharmaceutical companies to thwart TRIPS-compliant measures (authorising production of generics) instituted by South Africa and Brazil. ${ }^{43}$ Legal action against Brazil and South Africa was suspended following political pressure, but developing countries' policy freedom to use TRIPS flexibility articles ${ }^{44}$ remained uncertain and insecure. ${ }^{45}$ The Developing Country Group ${ }^{46}$ thus sought both greater clarity and an express agreement by WTO members that TRIPS "flexibilities" (such as Article 31) allow states to fashion their patent laws in ways that enable them to meet their public health objectives. ${ }^{47}$

Much of the Developing Country Group's Doha submission paper merely sought confirmation that TRIPS permits compulsory licensing and the parallel import of generic drugs when the listed requirements are fulfilled. However, the Group also highlighted the difficulties that Article 31 presented for states wishing to import generic medicines and called on the TRIPS Council to confirm that Article 31(f) did not prevent members from granting compulsory licences to supply foreign markets. ${ }^{48}$ Clearly, this was precisely what Article 31(f) was designed to curtail, and this submission effectively called for an amendment to the TRIPS treaty.

To a large extent the developing countries' arguments relied on TRIPS Article 7. This article had been inserted into TRIPS at their insistence (and is often regarded as one of the few "victories" for developing countries during the TRIPS negotiations). ${ }^{49}$ Article 7 is

42 Davinia Ovett "Making trade policies more accountable and human-rights consistent: a NGO perspective of using human rights instruments in the case of access to medicines" in Benedek, de Feyter \& Marrella (eds) Economic globalisation and human rights Cambridge University Press (2007) 170 at 176; Carlos Correa "Implications of the Doha Declaration on the TRIPS Agreement and Public Health" Health Economics and Drugs EMD Series no 12 World Health Organization (2002) Available at www.who.int (last visited August 2010) at 1; Lawrence Helfer "Regime shifting: the TRIPS Agreement and new dynamics of international intellectual property law making" (2004) 29 Yale Journal of International Law 1 at 66; Brook Baker "Arthritic flexibilities for accessing medicines: analysis of WTO action regarding paragraph 6 of the Doha Declaration on the TRIPS Agreement and Public Health" (2004) 14 Indiana International and Comparative Law Review 613 at 624-25.

43 The United States brought a complaint against Brazil's Patent Act Law 9.279/96 (See "Request for the Establishment of a Panel by the United States" WT/DS199/3 9 January 2001), and passed Public Law 105277 (1999), which threatened to suspend American aid to South Africa pending negotiations leading to the repeal of s 15(c) of the South African Medicines and Related Substances Control Amendment Act 90 of 1997. Pharmaceutical companies sued the South African Government (Pharmaceutical Manufacturers Association of South Africa and Another: In re ex parte President of the Republic of South Africa and Others 1999 (4) SA 788 (T); 2000 (2) SA 674 (CC)); see South African Delegation IP/C/M/31 at 27; James Harrison The human rights impact of the World Trade Organisation Hart (2007) at 159-160.

${ }^{44}$ For example, Article 31 permitting compulsory licensing.

45 Susan Sell "TRIPS and the Access to Medicines Campaign" (2002) 20 Wisconsin International Law Journal 481 at 492.

${ }^{46}$ A coalition of 80 developing countries led by the African group, India, and Brazil, and supported by an international coalition of NGOs including Médecins sans Frontières, Oxfam, and the Treatment Action Campaign. See Ovett (fn 42 above) at 176.

${ }^{47}$ See for example Developing Country Group's paper submitted at the WTO Ministerial Meeting on TRIPS and Public Health (29 June 2001) IP/C/W/296 para 5, and paras 17-23.

48 Developing Country Group's paper IP/C/W/296 para 34.

${ }^{49}$ See Note of the Secretariat Meeting of Negotiating Group 12-14 July 1989 MTN.GNG/NG11/14, 12 September 1989 for minutes of the discussions. For comment on the significance of Article 7 for developing countries see Watal (fn 24 above) and Drahos \& Braithwaite (fn 19 above). 
a formulation of the "balance and welfare-enhancing" principles which are universally recognised as foundational premises of the IP system, and sets out the objectives of the treaty as follows:

"The protection and enforcement of intellectual property rights should contribute to the promotion of technological innovation and to the transfer and dissemination of technology to the mutual advantage of producers and users of technological knowledge and in a manner conducive to social and economic welfare, and to a balance of rights and obligations." 50

During the TRIPS negotiations, developed countries resisted insertion of this paragraph ${ }^{51}$ and the final wording agreed upon is somewhat vague and non-specific. Furthermore, Article 7 uses the permissive verb "should" rather than the peremptory "shall" used in most TRIPS articles. At the time, developed state negotiators were reported as saying that Article 7 had no "operational significance" and was merely hortatory.52 Developing state negotiators, however, believed that future use and interpretation of Article 7 could be "one means of 'clawing' back much of what was lost in the negotiating battles in TRIPS". 53

This is what the Developing Country Group tried to do at Doha. The Group pointed out that Article 7 "clearly establishes that the protection and enforcement of intellectual property rights do not exist in a vacuum. They are supposed to benefit society as a whole and do not aim at the mere protection of private rights." 54 In the context of health pandemics, patent rights should be exercised in a way that achieves a balance between the rights of patent holders and the needs of users of patented medicines "in a manner conducive to social and economic welfare and to a balance of rights and obligations". ${ }^{5}$

The Group argued that the Article 31 compulsory licensing provisions should be interpreted in light of Article 7.56 Article 31(f) made it extremely difficult for developing countries to acquire the generic drugs needed to respond to the HIV/AIDS pandemic, with the effect that the private rights of patent holders were protected at the expense of public health and social welfare more generally. Developing countries submitted that Article 31(f) must be interpreted "flexibly and broadly" when applied to essential medicines required by developing countries. ${ }^{57}$ This would ensure that TRIPS did not "hamper people's access to affordable medicines, [or] stand in the way of urgently-needed solutions to the deepening health crisis". 58

The developing countries' Doha proposal is a typical balance and welfare-enhancing argument based on internal principles of the IP system. The weakness of this argument was that developed states could easily use the same internal principles against the developing states. Developed states did not dispute the public benefit objectives of the

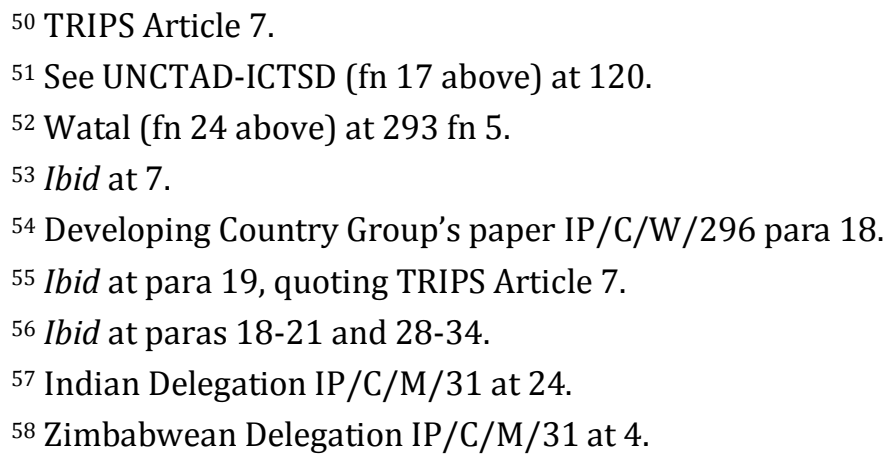


patent system. They agreed that this was precisely what the system was designed to achieve - development of useful new technologies like pharmaceuticals that promote public health. ${ }^{59}$ They argued, however, that high protection levels are essential to ensure that the system fulfils this objective. ${ }^{60}$ Pharmaceuticals require years of research and development (R\&D) and enormous financial investment. Testing and regulation requirements add significantly to the cost. According to some estimates, it can cost as much as US\$ 800 million to bring a new drug to market. ${ }^{61}$ Drug companies argue that in order to recoup their R\&D investment they require patent monopoly income well in excess of the simple manufacturing costs of pharmaceuticals and that patent monopoly prices accurately reflect the true cost of producing the drugs. ${ }^{62}$ Developed countries thus argued that patents "provide an essential stimulus for creativity and innovation. These rights need to be adequately protected in order to encourage investment in research and development into new medicines".63

When developing states pointed out that TRIPS requires protection of intellectual property rights to contribute to social welfare ${ }^{64}$ and provides that member states may adopt measures necessary to protect public health, ${ }^{65}$ developed states countered that intellectual property protection itself promotes public health and social welfare objectives by encouraging development of useful new medicines, and is indeed essential to this end. Without the drug companies' considerable investment in research and development, new medicines would not be developed, and there would be no drugs for the generics manufacturers to copy. ${ }^{66}$ In response it was argued that developing country markets do not form part of the drug companies' investment incentive. Pharmaceutical companies cannot reasonably expect to recoup their R\&D costs through sale of their products in developing countries: Africa comprises only 1.2 percent of the global market, India 1.3 percent and the rest of Asia 2.6 percent. ${ }^{67}$ Loss or reduction of these markets to generic competitors would have negligible effects on global originator drug profits. ${ }^{68}$

It has also been argued that originator companies do not need to sell their products at the full on-patent price in all markets. Drug companies could maintain their overall profit

\footnotetext{
${ }^{59}$ American Delegation IP/C/M/31 at 33.

${ }^{60}$ Ibid at 35.

${ }^{61}$ Christopher Holman "Do reverse payment settlements violate the antitrust law?" (2007) 23 Santa Clara Computer \& High Technology Law Journal 489 at 509. However, some studies dispute the drug companies' claims and estimate that figures are more "in the range of US\$50 - 100 million for each newly developed drug": Adila Hassim, Mark Heywood, Jonathan Berger Health \& democracy: a guide to human rights, health law and policy in post-apartheid South Africa SiberInk (2007) at 439.

62 Patricia Danzon \& Adrian Towse "Theory and implementation of differential pricing for pharmaceuticals" in Maskus \& Reichman (eds) International public goods and transfer of technology under a globalized intellectual property regime Cambridge University Press (2005) 425 at 428; see also CIPR (fn 40 above) at 29.

${ }^{63}$ EC Delegation IP/C/M/31 at 7.

64 TRIPS Art 7.

65 TRIPS Art 8(1).

${ }^{66}$ American Delegation IP/C/M/31 at 33; Cann (fn 41 above) at 794.

${ }^{67}$ DFID (fn 36 above) at 323; WHO (fn 41 above) at 236.

${ }^{68}$ Caroline Thomas "Trade policy and the politics of access to drugs" (2002) 23 Third World Quarterly 251 at 254 .
} 
margins (and possibly increase them) by selling more drugs to more people using differential pricing models: 69 that is, selling drugs at on-patent prices in developedcountry markets ${ }^{70}$ while selling them at prices closer to production cost in the developing world. According to economists, differential pricing always tends to be more profitable than selling commodities at the same price in all markets. ${ }^{71}$ With pharmaceuticals, such models allow companies to recoup their investment, and indeed maximise their profits, while still ensuring that the right to health of the poor is not endangered. ${ }^{72}$

Developing countries were always willing to pay licence fees under compulsory licensing schemes. Their proposals posed no financial prejudice to the drug companies and in no way undermined the ability of the patent system to incentivise pharmaceutical research and development. Despite this, developed countries insisted that patent rights need to be strong and that weakening these rights by facilitating compulsory licensing would not be in the long-term public interest; strong rights were essential for the development of new drugs from which everyone would benefit eventually. ${ }^{73}$

Although these arguments continued for three years, the Article 31(f) problem was never satisfactorily resolved. The deadline for acceptance of the temporary (and unsatisfactory) ${ }^{74}$ "Paragraph 6"75 solution to Article 31(f) has now been extended to December $2011^{76}$ and the compulsory licensing issue is once again under negotiation. ${ }^{77}$

${ }^{69}$ See Watal (fn 41 above) at 11.

${ }^{70}$ In practice, many pharmaceutical companies use differential pricing within developed-country markets too, with the result that not all developed-state consumers pay the full on-patent price. See Arti Rai "The information revolution reaches pharmaceuticals: balancing innovation incentives, cost, and access in the post-genomics era" 2001 University Illinois Law Review 173 at 188 for discussion of differential pricing practices in the United States and Carsten Fink "International price discrimination and market segmentation for patented pharmaceuticals in the EU: a social welfare analysis" in Govaere \& Ullrich (eds) Intellectual property, public policy and international trade Peter Lang (2007) 169 for discussion on differential pricing in Europe.

${ }^{71}$ CIPR (fn 40 above) at 35; Watal (fn 41 above) at 12. See also DFID (fn 36 above) at 32; Gifford (fn 10 above) at 115-116, discussing price discrimination in the global market as a way of minimising "deadweight loss" and thus maximizing overall profit.

72 CIPR (fn 40 above) at 41. See also Danzon \& Towse (fn 62 above) at 455; Watal (fn 41 above) at 12; Fink (fn 70 above) at 169. In the context of essential medicines, Pogge regards differential pricing models as morally correct also: Thomas Pogge "Human rights and global health: a research program" (2005) 36 Metaphilosophy 182 at 187.

${ }^{73}$ See American and EC Delegations.

${ }^{74}$ Médecins sans Frontières "Amendment to WTO TRIPS agreement makes access to affordable medicines even more bleak" 2005 MSF Article, available at www.msf.org (last visited April 2006) at 1. See also Thomas Cottier "The Doha Waiver and its effects on the nature of the TRIPS system and on competition law: the impact of human rights" in Govaere \& Ullrich (eds) Intellectual property, public policy and international trade (Peter Lang (2007) 173 at 178-179; Frederick Abbott \& Jerome Reichman "The Doha Round's public health legacy: strategies for the production and diffusion of patented medicines under the amended TRIPS provisions" (2007) 10 Journal of International Economic Law 921 at 921; Cann (fn 41 above) at 820; Baker (fn 42 above) at 655 .

75 Implementation Agreement of Paragraph 6 of the Doha Declaration on the TRIPS Agreement and Public Health, IP/C/W/405, 30 August 2003. Paragraph 6 makes it possible for states to export generic drugs to states meeting certain requirements but prescribes excessively cumbersome and expensive procedures. See the sources listed in footnote 74 for criticisms of Paragraph 6.

${ }^{76}$ See the announcement by the WTO General Council, 21 December 2009 (WT/L/785).

77 See Catherine Saez "Drug access waiver debate looms for June TRIPS Council Meeting" Intellectual Property Watch Archive available at http://www.ip-watch.org/weblog/archives/ (last visited June 2010). 
There is little reason to hope that the problem will be settled during current talks unless something new is brought into the discussion. Negotiations over patents and public health are impossible to finalise using only internal principles of intellectual property law because the debate straddles the tension inherent in the patent system - benefits of patent monopolies versus consequent social costs. Intellectual property law does not tell us when the social costs of the system become legally unacceptable.

States need, in addition, to use an "external" argument and look for norms outside of intellectual property law and principles to resolve this impasse. The human rights system provides clear standards and benchmarks which give legal content to the term "public benefit" and demarcate a bottom line below which the social costs of the international patent system become non-negotiable and potentially unlawful.

\section{ESTABLISHING HUMAN RIGHTS BENCHMARKS: ESSENTIAL MEDICINES}

Rules protecting the rights of patent holders are usually highly specific and have very effective enforcement machinery. ${ }^{78}$ In comparison, the human rights set out in treaties like the ICESCR seem vague, indeterminate, non-specific and unenforceable. ${ }^{79}$ It would be difficult to use ICESCR rights to counter rights set out in TRIPS and other IP treaties unless human rights were perceived as similarly precise obligations.

Until recently, social and economic rights were generally considered to be "jurisprudentially undeveloped" 80 and their normative content to be "obscure". 81 The ICESCR itself has been perceived as having little practical significance, its wording as vague and non-specific and the scope and content of the obligations not clearly spelled out. ${ }^{82}$ Some have argued that ICESCR rights could not function as peremptory norms because they "do not provide the guidance that a rule of law should provide". ${ }^{8}$

\footnotetext{
${ }^{78}$ Frederick Abbott "TRIPS and human rights: preliminary reflections" in Abbott, Breining-Kaufmann \& Cottier (eds) International trade and human rights: foundations and conceptual issues University of Michigan Press (2006) 145 at 161; Harrison (fn 42 above) at 169.

${ }^{79}$ Yuval Shany "Stuck in a moment in time: the international justiciability of economic, social and cultural rights" in Barak-Erez \& Gross (eds) Exploring social rights: between theory and practice Hart (2007) 77 at 82.

80 As Hunt puts it: they "lack[ed] a legal tradition": Paul Hunt Reclaiming social rights: international and comparative perspectives Ashgate (1996) at 69; Martin Scheinin "Economic and social rights as legal rights" in Eide, Krause \& Rosas (eds) Economic, social and cultural rights: a textbook 2 rev. ed. Martinus Nijhoff (2001) 29 at 31; Philip Alston "Out of the abyss: the challenges confronting the new U.N. Committee on Economic, Social and Cultural Rights" (1987) 9 Human Rights Quarterly 332 at 351); Paul Farmer with Nicole Gastineau "Legal and human rights intervention for health: rethinking health and human rights: time for a paradigm shift" 30 Journal of Law, Medicine \& Ethics 655 at 655; Scott Leckie "Another step toward indivisibility: identifying the key features of violations of economic, social and cultural rights" (1998) 20 Human Rights Quarterly 81 at 87.
}

${ }^{81}$ Hunt (fn 80 above) at 2.

82 Alston (fn 80 above) at 351 and 332-3; Magdalena Sepúlveda The nature of the obligations under the International Covenant on Economic, Social and Cultural Rights Intersentia (2003) at 132; Hunt (fn 80 above) at 112; Matthew Craven The International Covenant on Economic, Social and Cultural Rights: a perspective on its development Clarendon Press (1995) at 104.

83 Andras Sajo "Socioeconomic rights and the international economic order" (2002) 35 New York University Journal of International Law \& Policy 221 at 223. 
Furthermore, all ICESCR rights are subject to "progressive realization". Article 2(1) of the Convention calls for each state party to

"take steps ... to the maximum of its available resources, with a view to achieving progressively the full realization of the rights recognized in the present Covenant by all appropriate means, including particularly the adoption of legislative measures."

Historically, this reference to progressive realisation created a perception that the ICESCR does not create binding obligations in the same way as ICCPR ${ }^{84}$ rights (which are not subject to progressive realisation), especially as the ICESCR gives little guidance on what "achieving progressively" means or how progress should be measured. ${ }^{85}$

During the past two decades, however, human rights scholars have enriched jurisprudential understanding of the ICESCR ${ }^{86}$ by specifying the rights' core content, clarifying obligations, identifying specific violations, and generally raising the profile and legitimacy of social and economic rights. ${ }^{87}$ This "reclaiming" of social and economic rights has made it clear that the rights protected by the ICESCR are not fundamentally different from those protected by the ICCPR. It is now "generally accepted that rights in both categories are essentially similar" 88 and that "there is no sharp conceptual distinction between the two categories". 89

The United Nations Committee on Economic, Social, and Cultural Rights (CESCR) has been particularly important in this jurisprudential development. ${ }^{90}$ The CESCR, as the supervisory body for the ICESCR, ${ }^{91}$ from time to time, issues "General Comments" aimed at "clarify[ing] the normative issues [of the ICESCR] ...."92 These General Comments, though not legally binding in their own right, are "authoritative interpretations" of the binding clauses in the ICESCR intended as firm guidelines for practical implementation. ${ }^{93}$ States parties that fail to act on the Committee's recommendations "show bad faith in

${ }^{84}$ International Covenant on Civil and Political Rights, adopted 16 December 1966, entered into force 23 March 1976 (1967) 6 ILM 368.

85 See Henry Steiner \& Philip Alston (eds) International human rights in context: law, politics, morals Oxford University Press (2000) at 246.

${ }^{86}$ See for example, Hunt (fn 80 above); Alston (fn 80 above); Philip Alston \& Gerard Quinn "The nature and scope of states parties' obligations under the International Covenant on Economic, Social and Cultural Rights" (1987) 9 Human Rights Quarterly 156 at 184; and the contributions to Eide, Krause \& Rosas (eds) Economic, social and cultural rights: a textbook 2 rev. ed. Martinus Nijhoff (2001).

${ }^{87}$ Sage Russell "Minimum state obligations: international dimensions" in Brand \& Russell (eds) Exploring the core content of socio-economic rights: South African and international perspectives Protea Book House (2002) 11 at 11.

88 Leckie (fn 80 above) at 88.

${ }^{89}$ Hunt (fn 80 above) at 69. See also Sepúlveda (fn 82 above) at 134; Alston \& Quinn (fn 86 above) at 184; and the contributions to Eide et al (fn 86 above).

90 The Committee's General comments are particularly important in this regard. See note 96 below.

${ }^{91}$ Sepúlveda (fn 82 above) at 29, 32, 89-90; Alston (fn 80 above) at 332.

${ }_{92}$ Comment made by the Committee in the Summary Record of the $28^{\text {th }}$ meeting, held on 15 November 1999 (UN Doc E/C.12/1999/SR.28) para 41.

${ }_{93}$ The Committee itself regards its General comments as "authoritative interpretations" of the ICESCR, and has described them as such in E/C.12/1999/11 para 441 and E/C.12/1999/11 para 52. See also Hans Haugen "General Comment No 17 on 'authors' rights"' (2007) 10 Journal of World Intellectual Property 53 at 55, noting that the General comments are the "most authoritative clarification" of the ICESCR. 
implementing their Covenant-based obligations",94 a contravention of Article 26 of the Vienna Convention on the Law of Treaties (VCLT). ${ }^{95}$

The CESCR has examined many of the ICESCR rights in detail. ${ }^{96}$ It has established clear benchmarks and has identified specific conduct that will be regarded as violating ICESCR obligations. This jurisprudential development has enormous advantages for those who want to rely on human rights to counter the very precise and specific protectionist rules in the IP treaties. ${ }^{97}$

One of the jurisprudential tools used by the CESCR is the "tripartite typology" which shows that all human rights give rise to duties to "respect", "protect" and "fulfil" the rights. The duty of respect requires states to refrain from any action which would interfere with a particular right: "[t]he broad idea is not to worsen an individual's situation by depriving that person of the enjoyment of a declared right". ${ }^{98}$ The obligation to protect requires states to "prevent violations of such rights by third parties". ${ }^{99}$ The obligation to fulfil requires states "to take appropriate legislative, administrative, budgetary, judicial and other measures toward the full realization of such rights". 100

Another useful tool is the identification of the "minimum core" of the ICESCR rights. Minimum core rights are non-derogable in principle ${ }^{101}$ and states must take immediate steps towards their implementation. ${ }^{102}$ The minimum core concept is extremely useful for policy-setting and bench-marking and could be a powerful tool in international negotiation. ${ }^{103}$

The CESCR has also explained that progressive realization

\footnotetext{
94 Sepúlveda (fn 82 above) at 88.

95 Ibid.

96 The Committee's General Comments on specific ICESCR rights include General Comments on the right of everyone to take part in cultural life (General Comment 21); on the right to work (General Comment 6); the right to food (General Comment 12); the right to education (General Comment 13); the right to water (General Comment 15); and the right to housing (General Comments 4 and 7). It has also issued comments on more general obligations such as General comment 3 on the nature of states' obligations, General Comment 8 on economic sanctions and General Comment 9 on the domestic application of the Covenant. All CESCR General comments are available at http://www2.ohchr.org/english/ bodies/cescr/comments.htm.

97 Robert Wai "Countering, branding, dealing: using economic and social rights in and around the international trade regime" (2003) 14 European Journal of International Law 35 at 111; Harrison (fn 42 above) at 169.

98 Steiner \& Alston (fn 85 above) at 182.

99 Maastricht Guidelines on Violations of Economic, Social and Cultural Rights (1998) 20 Human Rights Quarterly 691 para 6.

100 Ibid.

101 Audrey Chapman "Core obligations related to the right to health and their relevance for South Africa" in Brand \& Russell (eds) Exploring the core content of socio-economic rights: South African and international perspectives Protea Book House (2002) 35 at 37; Russell (fn 87 above) at 16; CESCR General Comment 14 para 47.

102 CESCR General Comment 3 The nature of states parties' obligations (UN Doc E/1991/23) para 1; Leckie (fn 80 above) at 93.

103 For criticism of use of the minimum core in other ways see Karin Lehmann "In defense of the Constitutional Court: litigating socio-economic rights and the myth of the minimum core" (2006) 22 American University International Law Review at 163; Russell (fn 87 above) at 16.
} 
"should not be interpreted as removing all meaningful content from States parties' obligations. Rather, it means that States parties have a specific and continuing obligation to move as expeditiously and effectively as possible towards the full realization of [the rights]."104

States have immediate obligations to "take steps" toward the full realization of the ICESCR rights. ${ }^{105}$ Examples of such steps include legislation aimed at achieving a right ${ }^{106}$ or the development and implementation of "targeted, legally consistent, and sufficiently progressive policies" aimed at the full realisation of economic and social rights. ${ }^{107}$

In the context of international IP negotiation, one of the best developed rights is the right to essential medicines based on the ICESCR right to health (Article 12) as examined by the CESCR in its General Comment 14: The right to the highest attainable standard of health. ${ }^{108}$ The Committee identifies provision of "essential medicines" as part of the "minimum core" of the right to health. ${ }^{109}$ "Essential medicines" are defined as those listed by the World Health Organisation (WHO) in terms of its Action Programme on Essential Drugs. ${ }^{110}$ The WHO list does not include the latest groundbreaking therapies; it is mostly restricted to older, patent-free and affordable basic medicines. ${ }^{111}$ However, because antiretroviral drugs are the only realistic way to control the HIV/AIDS pandemic, ${ }^{112}$ the WHO added several antiretrovirals to the essential medicines list even though most were still under patent and very expensive when they were first included. In this regard, the Organisation has encouraged and assisted states to use TRIPS flexibilities (like Article 31) to enable them to procure essential medication at lower prices. ${ }^{113}$

The WHO advises states to adopt pharmaceutical policies designed to make essential medicines more affordable, especially where the listed medicines are still under patent. ${ }^{114}$ These pharmaceutical policies should include policies on generics, pricing

104 CESCR General Comment 14 para 31.

105 CESCR General Comment 3 para 1; Similar language is used in CESCR General Comment 14 para 30. That is to say, the very obligation to "take steps" set out in ICESCR Article 2(1) is of an immediate nature: (Leckie (fn 80 above) at 93; Sepúlveda (fn 82 above) at 134).

106 CESCR General Comment 3 para 3.

107 Leckie (fn 80 above) at 93.

108 CESCR General Comment 14.

109 General Comment 14, para 43(d).

110 Ibid para 43(d).

111 World Health Organization "Selection of Essential Medicines" (2002) 4 WHO Policy Perspectives on Medicines 1 available at www.who.int (visited August 2010); Danwood Chirwa "The right to health in international law: its implications for the obligations of state and non-state actors in ensuring access to medicine" (2003) 19 SAJHR 541 at 554.

112 CIPR (fn 40 above); World Health Organization "Intellectual property rights, innovation and public health: report by the Secretariat" 12 May 2003 (A56/17). Available at www.who.int (visited November 2006) para 17; DFID (fn 36 above); Médecins sans Frontières "A matter of life and death: the role of patents in access to essential medicines: MSF Briefing Document for the $4^{\text {th }}$ WTO Ministerial Conference in Doha, Qatar, November 9-13, 2001" 2001 MSF Article, available at www.msf.org (visited August 2010).

113 Xavier Seuba "Human rights and intellectual property rights provisions" in Correa \& Yusuf (eds) intellectual property and international trade: the TRIPS Agreement 2 ed. Wolters-Kluwer (2008) 387 at 402.

114 See the WHO bulletin Essential Drugs in Brief for overviews of various states' pharmaceutical strategies (available at http://www.who.int/medicines/publications/brief/en/; visited December 2010). 
policies, bulk procurement policies, differential pricing structures, compulsory licensing, parallel importation, price negotiation with drug companies and other strategies designed to ensure that prices of essential drugs are kept as low as possible. ${ }^{115}$

The CESCR identifies the adoption and implementation of national public health strategies and action plans as minimum core obligations. ${ }^{116}$ These health strategies should include pharmaceutical strategies. Special Rapporteur Paul Hunt confirms that "the State has to do all it reasonably can do to make an essential medicine available in its jurisdiction, e.g. by using, where appropriate, TRIPS flexibilities, such as compulsory licences and parallel imports". ${ }^{117}$ Pharmaceutical policies must be aimed at acquiring essential medicines from reliable suppliers at the lowest possible prices, thus ensuring that essential drugs are available and affordable, particularly to the poor. ${ }^{118}$

States' non-derogable minimum core obligation to provide essential medicines is perhaps best understood by considering the obligation to provide medicines ${ }^{119}$ together with the obligation to adopt pharmaceutical strategies: ${ }^{120} \mathrm{~A}$ state's available resources may make it impossible to purchase and distribute HIV/AIDS drugs to all residents immediately, but it must make the best effort possible within available resources, including efforts to obtain essential medicines at affordable prices. Most importantly, states have immediate and non-derogable duties to establish appropriate pharmaceutical programmes and policies. In the context of essential medicines, pharmaceutical strategies and policies are crucial steps towards making antiretroviral medicines available, and the ability to issue compulsory licences is a key component of the strategy. Not only does this enable states to procure cheaper drugs directly from generics manufactures; it also enables them to negotiate better prices with originator companies. ${ }^{121}$ States must ensure that they retain sufficient patent policy flexibility so that they can establish suitable pharmaceutical policies, and thereby meet these immediate and non-derogable core obligations.

The CESCR has also examined ICESCR states' obligations to people in foreign countries. Member states have extraterritorial obligations "to respect the enjoyment of the right to health in other countries". 122 States' international IP and trade policies violate this obligation of respect if they make it more difficult for people in foreign countries to acquire essential medicines (for example by making it harder for other states to adopt appropriate pharmaceutical policies). ${ }^{123}$ Thus, ICESCR members should ensure that

\footnotetext{
115 World Health Organization "How to develop and implement a national drug policy" (2003) 4 WHO Policy Perspectives on Medicines 4. The South African National Drug Policy, 1996 is a good example of this type of pharmaceutical policy.

116 CESCR General Comment 14 Para 43(f).

${ }^{117}$ Hunt (fn 6 above) para 35.

118 Alicia Yamin "Not just a tragedy: access to medications as a right under international law" (2003) 21 Boston University International Law Journal 325 at 327.

119 CESCR General Comment 14 para 43(d).

120 Ibid para 43(f).

${ }^{121}$ CIPR (fn 40 above) at 42; Christopher May \& Susan Sell Intellectual property rights: a critical history Lynne Rienner (2006) at 170.

122 CESCR General Comment 14 para 39.

${ }^{123}$ Ibid para 50.
} 
international agreements and instruments do not have a negative impact on the right to health in other countries. ${ }^{124}$ This applies also to states parties' actions as members of international organisations: ICESCR members have a duty to ensure that the actions of these organisations respect the right to health in all parts of the world. ${ }^{125}$

The CESCR has also examined the human rights implications of "the public interest". The Committee has emphasised that state public welfare policies must be nondiscriminatory and should focus particularly on the most vulnerable sectors of the population. In the context of the right to health, for example, states have a particular duty to provide health care to the poor, and equality of access to health care is listed as part of the minimum core of the right. ${ }^{126}$ Special Rapporteur Paul Hunt points out that nondiscrimination and equality of access imply "a particular preoccupation with those who are disadvantaged, vulnerable and living in poverty".127

\section{USING HUMAN RIGHTS BENCHMARKS}

At Doha, the Developing Country Group demanded confirmation that TRIPS flexibilities allowed them to establish national health care and pharmaceutical programmes to respond to the HIV/AIDS crisis and to procure generic drugs from reliable sources of their choice. They based these demands on their public health care needs and on TRIPS Article 7. What they did not do, however, was link these demands to the obligations arising from the ICESCR. General Comment 14 offered them clear benchmarks; as noted above, it insists that ICESCR member states have binding minimum core obligations to establish pharmaceutical policies that enable them to procure essential medicines at the lowest possible prices ${ }^{128}$ and to respect the right to health in foreign countries by not adopting or interpreting treaties in ways which make it more difficult for governments to establish pharmaceutical policies that promote availability of essential drugs. ${ }^{129}$ The failure to examine human rights obligations during the Doha talks may seem particularly surprising because almost all WTO and members are also ICESCR states parties. ${ }^{130}$

Human rights scholars have used General comment 14 in various ways to examine the right to essential medicines. The strongest form of the argument demonstrates a potential conflict between ICESCR obligations and TRIPS obligations and argues that

\footnotetext{
124 Ibid paras 19 and 39.

125 Ibid para 39.

126 Ibid paras 19 and 43(a). See also David Weissbrodt \& Connie de la Vega International human rights law: an introduction University of Pennsylvania Press (2007) at 138.

127 Hunt (fn 6 above) paras 25-26. See also Aeyal Gross "The right to health in an era of privatisation and globalisation: national and international perspectives" in Barak-Erez \& Gross (eds) Exploring social rights: between theory and practice Hart (2007) 289 at 306 and Audrey Chapman "A 'violations approach' for monitoring the International Covenant on Economic, Social and Cultural Rights" (1996) 18 Human Rights Quarterly 23 at 44.

128 CESCR General Comment 14 para 43. "Lowest possible prices" applies primarily to states which are poorly resourced and cannot afford full on-patent prices.

129 Ibid paras 19, 39, 50.

130 All but 26 of 152 current WTO member states have ratified the ICESCR (WTO webpage at www.wto.org ; United Nations High Commissioner webpage at www2.ohchr.org/english/bodies/cescr/ (visited July 2010).
} 
ICESCR member states must reconcile this conflict by interpreting TRIPS in a human rights-compliant manner. ${ }^{131}$

This argument begins with the observation that states which have ratified human rights treaties violate their commitments if they enter into other agreements which are incompatible with their existing human rights obligations. ${ }^{132}$ The specification of ICESCR obligations by the CESCR appears to demonstrate a potential conflict between states' treaty obligations under and TRIPS and the ICESCR. ${ }^{133}$ For example, limitations on the export of generic drugs imposed by TRIPS Article 31(f) would appear to conflict with states' duties to maintain enough IP policy space to establish appropriate pharmaceutical policies or to respect the right to health in foreign states. ${ }^{134}$

States have a duty to uphold all their treaty commitments in terms of Article 26 of the VCLT. ${ }^{135}$ In order to avoid conflict between their various treaty commitments, states are obliged to interpret the treaties that bind them in ways that avoid conflict and allow them to fulfil all their obligations. ${ }^{136}$

The CESCR has made it clear that ICESCR member states have certain non-derogable minimum-core obligations under that treaty. The challenge for these states is to interpret and implement their TRIPS commitments in a human rights-compliant manner which does not conflict with their ICESCR obligations. ${ }^{137}$ It is possible for ICESCR states to abide

131 See for example, Jonathan Berger "The global AIDS crisis: tripping over patents: AIDS, access to treatment and the manufacturing of scarcity" (2002) 17 Connecticut Journal of International Law 157; Caroline Drommen "Safeguarding the legitimacy of the multilateral trading system: the role of human rights law" in Abbott, Breining-Kaufmann \& Cottier (eds) International trade and human rights: foundations and conceptual issues University of Michigan Press (2006) 121; Simon Walker "A human rights approach to the WTO's TRIPS Agreement" in Abbott, Breining-Kaufmann and Cottier (above) at 171; Yamin (fn 118 above).

132 Smita Narula "The right to food: holding global actors accountable under international law" (2006) 44 Columbia Journal of Transnational Law 691 at 743. The European Commission on Human Rights adopted this approach in $X \& X v F R G, 1958$ Year Book of the European Convention on Human Rights 256 at 300, and in $M$ \& Co $v$ FRG 1990 Year Book of the European Convention on Human Rights 51, as did the European Court of Human Rights in Matthews v UK 1999-I Eur Ct HR 251.

133 United Nations Sub-Commission on the Promotion and Protection of Human Rights Resolution 2000/7 Intellectual Property Rights and Human Rights (52 ${ }^{\text {nd }}$ Session, $25^{\text {th }}$ meeting, 2000). UN Doc E/CN.4/Sub.2/Res/2000/7.

134 This particular example of conflict meets the requirements for both "broad" and "narrow" understandings of conflict. See International Law Commission Fragmentation of international law: difficulties arising from the diversification and expansion of international law . Final report of the Study Group of the International Law Commission, finalized by Martti Koskenniemi. UN Doc A/CN.4/L/682 (13 April 2006). Available at http://www.un.org/law/ilc/index.htm (last visited March 2008) paras 25-25; Joost Pauwelyn Conflict of norms in public international law: how WTO law relates to other rules of international law Cambridge University Press (2003) at 184-188.

135 Vienna Convention on the Law of Treaties adopted March 23 1969, entered into force 27 Jan 1980 (1969) 8 ILM 679. Article 26.

136 David Weissbrodt \& Kell Schoff "Human rights approach to intellectual property protection: the genesis and application of Sub-Commission Resolution 2000/7" (2003) 5 Minnesota Intellectual Property Law Review 1 at 13; Gabrielle Marceau "The WTO dispute settlement and human rights" in Abbott, Breining-Kaufmann \& Cottier (fn 131 above) at 207; Hans Haugen The right to food and the TRIPS Agreement Nijhoff (2007) at 60; Sajo (fn 83 above) at 227; Helfer (fn 42 above) at 75; ILC (fn 134 above) para 37; Pauwelyn (fn 134 above) at 240.

137 See Walker (fn 6 above); Harrison (fn 42 above) at 143. 
by all their treaty commitments in terms of both ICESCR and TRIPS provided that full use is made of TRIPS flexibilities and TRIPS exception clauses are interpreted in a way which is human rights-compliant. ${ }^{138}$

In terms of the strong version of the human rights argument, all ICESCR member states at Doha should have insisted that Article 31(b) be interpreted "flexibly and broadly",139 not only because of the general "balance and welfare-enhancing" objectives of the TRIPS treaty set out in Article 7 but also because their ICESCR commitments mandate an interpretation giving states enough patent policy flexibility to establish the necessary pharmaceutical policies. ${ }^{140}$

Reliance on ICESCR obligations during negotiation has certain strategic advantages for developing countries. The high status of human rights instruments such as the ICESCR and the specificity achieved by the CESCR provide developing states with an "interpretative basis ... that is missing in simple policy arguments about social concerns". ${ }^{141}$ Human rights standards provide specific limitations on what is negotiable, while identifying precise minimum conditions that are beyond negotiation. They provide "a solid normative basis for values and policy choices which otherwise are more readily negotiable". ${ }^{142}$

There are also practical benefits in identifying binding human rights standards. When values are established as binding norms they acquire important symbolic power. ${ }^{143}$ Liberal democratic governments are usually motivated to obey the law or appear to be law-abiding. ${ }^{144}$ Members of civil society expect their governments to meet their international obligations. ${ }^{145}$ Conduct in violation of human rights might provoke moral outrage, but non-compliance with a binding rule of international law "carries its own, additional stigma, undermining the capacity of violators to defend their conduct, while enhancing the force of condemnation".146 Faced with a well-developed human rights-

138 Walker (fn 6 above); Robert Howse \& Makau Mutua "Protecting human rights in a global economy: challenges for the World Trade Organization" (2000) available at www.ichrdd.ca/english/ commdoc/publications/globalization/wtoRightsGlob.html (visited December 2010) at "Conclusion".

$139 \mathrm{Cf}$ Indian Delegation IP/C/M/31 at 24.

140 These scholars also consider the complex question of whether it is permissible to consider external treaties when interpreting TRIPS. They put forward a variety of arguments in favour of this. The simplest argument is based on the VCLT rules of interpretation requiring the WTO agreements to be interpreted with regard to "any relevant rules of international law applicable in the relations between the parties". (VCLT Article 31(3)(c)). See José Alvarez "How not to link: institutional conundrums of an expanded trade regime" (2001) 7 Widener Law Symposium Journal 1 at 3-4. See also James Harrison (fn 42 above) at 55-56, noting that the WTO dispute resolution machinery has itself many times considered issues with human rights, environmental and other 'non-trade' implications, has considered itself competent to do so, and had this jurisdictional competence accepted by the parties and WTO members generally.

141 Wai (fn 97 above) at 54.

142 Mac Darrow Between light and shadow: the World Bank, the International Monetary Fund and international human rights law Hart (2003) at 5.

${ }^{143}$ Abram Chayes \& Antonia Chayes “On compliance” (1993) 47 International Organization 175 at 185.

144 Ibid at 187.

${ }^{145}$ Harold Koh "Why do nations obey international law?" (1997) 106 Yale Law Journal 2599 at 2654. See also Ian Johnstone "The power of interpretive communities" in Barnett \& Duvall (eds) Power in global governance Cambridge University Press (2005) at 187.

${ }^{146}$ Douglass Cassel "Does international human rights law make a difference?'”(2001) 2 Chicago Journal of International Law 121 at 129. 
based case, liberal administrations will be obliged to account for their actions and, in most cases, will also feel obliged to meet their obligations. ${ }^{147}$

For human rights standards to have practical effect in international forums they must become "internalized" 148 by the governments involved. Norm internalisation is achieved when norms are repeatedly raised and discussed in negotiation until eventually they acquire their "stickiness". ${ }^{149}$ Developing countries could promote internalisation of ICESCR norms by repeatedly relying on them during negotiations.

Norm internalisation can also be promoted by activities of other actors such as international organisations, NGOs and human rights experts in the legal and academic communities, who can explore and publicise the human rights implications of IP protection. ${ }^{150}$ This leads to human rights consciousness-raising among the general public (who can put pressure on their governments) as well as within governments directly. ${ }^{151}$

A weaker version of the human rights argument does not rely on international human rights as legally binding rules but examines their potential value as soft-law norms. This approach is particularly useful when considering the position of the United States, which has not yet ratified the ICESCR but is a signatory to the Convention as well as to the nonbinding Universal Declaration of Human Rights, ${ }^{152}$ which also protects the right to health. ${ }^{153}$

The soft-law approach argues that even if the human rights norms are not binding, they nevertheless provide useful benchmarks for examination. They provide a credible foundation for critical consideration of the interests of users of patented products and of public welfare more broadly. Developing states raising such concerns would not merely be stating unilateral preferences; rather, they would be urging the global community to abide by international human rights standards that are almost universally accepted. ${ }^{154}$

147 Bruce Cronin "The paradox of hegemony: America's ambiguous relationship with the United Nations" (2001) 7 European Journal of International Relations 103 at 110 and 112; Lawrence Helfer \& Anne-Marie Slaughter "Toward a theory of effective supranational adjudication" (1997) 107 Yale Law Journal 273 at 278.

148 Koh (fn 145 above) at 2650.

$149 \mathrm{Ibid}$ at 2655. Other scholars have examined this process in more detail. See for example Jeffrey Checkel "Why comply? Social learning and European identity change" (2001) 55 International Organization 553 looking at "argumentative persuasion and social learning"; Ryan Goodman \& Derek Jinks "How to influence states: socialization and international human rights law" (2004) 54 Duke Law Journal 621 examining the role of acculturation in the norm internalization process.

150 Thomas Risse, Stephen Ropp \& Kathryn Sikkink (eds) The power of human rights: international norms and domestic change Cambridge University Press (1999) at 18; Sangmin Bae When the state no longer kills: international human rights norms and the abolition of capital punishment State University of New York Press (2007) at 16; Rosemary Foot Rights beyond borders: the global community and the struggle over human rights in China Oxford University Press (2000) at 9; Richard Falk "Taking human rights seriously at home" (1997) 68 Political Quarterly 179 at 180.

151 Koh (fn 145 above) at 2654. See also Anne-Marie Slaughter $A$ new world order Princeton University Press (2005).

152 Universal Declaration of Human Rights, adopted 10 December 1948. GA Res 217A (III), UN Doc A/810

71 (1948).

${ }^{153}$ Article 25.

154 Wai (fn 97 above) at 54. 
Considered in this way, human rights can be used to generate "counterregime norms" which provide alternative ways of looking at the treaty norms developed in the WTO155 and challenge the hegemony of the idea that IP protection can be championed with little regard to the possible effects on the public interest. ${ }^{156}$ The political impact of soft-law norms should not be underestimated. ${ }^{157}$

Human rights are also useful for framing positive agendas. ${ }^{158}$ UN High Commissioner for Human Rights Mary Robinson notes that all decision-makers should "draw upon human rights standards in ways that will help to improve the transparency and accountability and quality of their decisions". ${ }^{159}$ Taking human rights into account may suggest additional indicators for examination, may assist in choosing among policy options, and will focus attention on the potential outcomes of proposed policies and programmes. ${ }^{160}$

\section{THE DEVELOPMENT AGENDA}

The WIPO Development Agenda discussions respond to attempts within WIPO to limit patent policy flexibility through a new Substantive Patent Law Treaty. ${ }^{161}$ However, they also respond more generally to protectionist trends in international IP law evident in TRIPS and in bilateral and regional trade agreements.

The WIPO Development Agenda can be understood as an attempt by developing countries to move the IP discussion beyond the internal balance and welfare-enhancing discussions that had proved so frustrating at Doha. The Development Agenda proposals broaden the discussion to include wider development concerns and refer to documents that were drafted outside of the WTO and WIPO,162 including high status international documents such as the Millennium Development Goals (MDGs). ${ }^{163}$

\footnotetext{
${ }^{155}$ Helfer (fn 42 above) at 14.

156 It would be a way to "subvert the prevailing legal landscape and provide fuel for renegotiating principles, norms, and rules to reflect their interests more accurately": Helfer (fn 42 above) at 59.

157 See Robyn Eckersley "Soft law, hard politics, and the Climate Change Treaty" in Reus-Smit (ed) The politics of international law Cambridge University Press (2004) 80 discussing the political impact of the non-binding United Nations Framework Convention on Climate Change and concluding that an assumption that "only binding legal norms are consequential would seem to be ... naïve" (at 87).

158 Mary Robinson "What rights can add to good development practice" in Alston \& Robinson (eds) Human rights and development: towards mutual reinforcement Oxford University Press (2005) 25 at 33; See also Lawrence Helfer "Toward a human rights framework for intellectual property" (2007) 40 UC Davis Law Review 971 at 974.

159 Robinson (fn 158 above) at 35.

160 Ibid.

161 Sisule Musungu \& Graham Dutfield "Multilateral agreements and a TRIPS-plus world: the World Intellectual Property Organisation (WIPO)" (2003) TRIPS issues papers 3. Available at www.geneva.quno.info. (Last visisted August 2010).

162 For example, the Programme of Action for the Least Developed Countries for the Decade 2001-2010, the Johannesburg Declaration on Sustainable Development and the Plan of Implementation, and the Sao Paulo Consensus (Argentina-Brazil Development Agenda for WIPO (WO/GA/31/11) Annex section I; GDF Proposal IIM/1/4 para 2).

163 Argentina-Brazil Development Agenda for WIPO (WO/GA/31/11) Annex section I; GDF Proposal IIM/1/4 para 2.
} 
However, the Development Agenda process has also become mired in "internal" IP debates, as will be discussed below.

\subsection{The Development Agenda Proposals}

The Development Agenda discussions were based on documents put forward by a coalition of developing countries in $2004^{164}$ and 2005. 165 Many of the concerns expressed by "The Group of Friends of Development" (GFD) 166 involve the internal workings of the WIPO staff and secretariat. This article, however, focuses on the GFD proposals that concern intellectual property norm-setting more broadly.

To some extent the Development Agenda documents are based on the familiar "balance and welfare-enhancing" arguments that were largely ineffective at Doha. The GFD points out that "intellectual property protection is not an end in itself, but rather a means to support public policy objectives such as economic, social, and cultural well-being" 167 and stresses that the social costs of monopoly protection must always be balanced against the likely benefits. ${ }^{168}$ In this regard the GFD emphasises the need for operable public interest flexibilities in international IP agreements ${ }^{169}$ so that states have enough IP policy space to promote domestic policy goals. ${ }^{170}$

However, the GFD also makes some new arguments. These highlight "development" as the "most important challenge facing the international community," 171 and argue that "the development dimension" should be integrated into all WIPO's activities. ${ }^{172}$ The GFD documents express concern about the uncritical approach to IP protection endorsed by some developed states. This uncritical perspective tends to approach intellectual property protection "as if it were governed by absolute truths". ${ }^{173}$ These "absolute truths" include the assumption that "development" is an automatic consequence of strengthening

\footnotetext{
164 Proposal for the establishment of a Development Agenda for WIPO Argentina-Brazil Development Agenda for WIPO (WO/GA/31/11). Eight more developing countries (Bolivia, Cuba, Ecuador, Iran, Kenya, Sierra Leone, Tanzania and Venezuela) decided to co-sponsor the proposal. This was formally communicated to the WIPO Membership on 24 September 2004 (WO/GA/31/14).

${ }_{165}$ Proposal to establish a Development Agenda for WIPO: an elaboration of issues raised in document WO/GA/31/11 GDF Proposal IIM/1/4.

166 A coalition of 14 developing states: Argentina, Bolivia, Brazil, Cuba, Dominican Republic, Ecuador, Egypt, Iran, Kenya, Peru, Sierra Leone, South Africa, Tanzania and Venezuela.

167 GDF Proposal IIM/1/4 para 44.

168 GDF Proposal IIM/1/4 para 9; Argentina-Brazil Proposal WIPO WO/GA/31/11 Annex section II.

169 Argentina-Brazil Development Agenda for WIPO (WO/GA/31/11) Annex section IV; GDF Proposal IIM/1/4 para 9.

170 GDF Proposal IIM/1/4 para 21 (a).

${ }^{171}$ Argentina-Brazil Development Agenda for WIPO (WO/GA/31/11) Annex section I.

172 Argentina-Brazil Development Agenda for WIPO (WO/GA/31/11) Annex section III; GDF Proposal IIM/1/4 paras 11- 35.

173 GDF Proposal IIM/1/4 para 5.
} 
intellectual property rights ${ }^{174}$ and that "higher protection levels are always and inherently beneficial in promoting development and innovation".175

The GFD documents point out that the impact of IP protection varies in different economic and social contexts and that it is very unlikely that IP standards deemed appropriate to developed economies will have the same effect in developing and leastdeveloped states. Indeed, it is possible that they will impede development. ${ }^{176}$ They also demand a critical examination of the impact of proposed levels of protection on "the public interest, innovation and access to science, technology and the promotion of diverse national creative industries - in order to ensure material progress and welfare in the long run". 177

\subsection{Examining "absolute truths": Do stronger patents promote innovation and development?}

If patent monopolies encourage innovation, one might assume that more stringent and powerful patents will encourage more innovation. Economists, however, know that the link between patent strength and innovation is much more complicated. This is because almost all innovation is cumulative. ${ }^{178}$ Those engaged in new research build on the work of their predecessors and often need access to use research tools (for example, gene fragments) which are still under patent.

This dynamic affects pharmaceutical research particularly. Modern biomedical and pharmaceutical research relies on the use of genes, proteins and other gene fragments. ${ }^{179}$ Often, these essential research tools are under patent. This has created significant difficulty for scientists. Many scientists have reported that important research has been impeded by, for example, gene patenting. ${ }^{180}$ Problems arise when patent holders

\footnotetext{
174 Ibid paras 4 and 37.

175 Ibid.

176 Argentina-Brazil Development Agenda for WIPO (WO/GA/31/11) Annex section II.

177 Ibid para 7.
}

178 Suzanne Scotchmer "Standing on the shoulders of giants: cumulative research and the patent law" (1991) 5 Journal of Economic Perspectives 29; Merges and Nelson (fn 13 above); Graham Dutfield \& Uma Suthersanen "The innovation dilemma: intellectual property and the historical legacy of cumulative creativity" (2004) 4 Intellectual Property Quarterly 379.

179 See Helen Berman \& Rochelle Dreyfuss "Reflections on the science and law of structural biology, genomics, and drug development" (2006) 53 UCLA Law Review 871.

180 Eric Campbell et al "Data withholding in academic medicine: characteristics of faculty denied access to research results and biomaterials" (2000) 29 Research Policy 303; Rebecca Eisenberg "Bargaining over the transfer of proprietary research tools: is the market failing or emerging?" in Cooper, Zimmerman \& First (eds) Expanding the boundaries of intellectual property law: innovation policy for the knowledge society Oxford University Press (2001) 223; United States. National Institute of Health. Working Groups on Research Tools. Report of the National Institute of Health (NIH) Working Group on Research Tools. Presented to the Advisory Committee of the Director, June 4, 1998 . Available at http://www.nih.gov/news/researchtools/; Michael Heller \& Rebecca Eisenberg "Can patents deter innovation? The anticommons in biomedical research" (1998) 280 Science 698; C Ford Runge \& Edi Defrancesco "Exclusion, inclusion, and enclosure: historical commons and modern intellectual property" (2006) 34 World Development 1713 at 1721; Nikolaus Thumm "Patents for genetic inventions: a tool to promote technological advance or a limitation for upstream inventions?" (2005) 25 Technovation 1410 at 
refuse to issue research licences, charge exorbitant prices or impose licensing conditions which restrict publication of research results or limit collaboration within the scientific community. ${ }^{181}$ Very often a project requires the use of many protected products and becomes mired in a logistical nightmare of patent negotiation; ${ }^{182}$ at worst, projects become financially impossible. ${ }^{183}$ These problems are particularly evident in developing countries, where scientists are comparatively under-resourced, ${ }^{184}$ and for those researching "unprofitable diseases" like malaria and tuberculosis which primarily affect poor people. 185

Hundreds of economic studies have investigated the relationship between patent strength and the promotion of innovation. ${ }^{186}$ These studies show that there is a delicate, complex, and largely unpredictable relationship between patenting and innovation. ${ }^{187}$ Economists have been unable to identify the precise level at which patent strength becomes a barrier rather than an incentive. Most agree, however, that strengthening patent protection does not always promote innovation and that there is a point at which it tends to have the opposite effect. ${ }^{188}$ Economists also agree that patent strength will

1411; Aldo Geuna \& Lionel Nesta "University patenting and its effects on academic research: the emerging European evidence" (2006) 35 Research Policy 790.

181 See the studies listed in footnote 180 above.

182 See particularly the in-depth analysis in Heller \& Eisenberg (fn 180 above).

183 See for example the studies discussed by Runge \& Defrancesco (fn 180 above) at $1721 \mathrm{ff}$ and by Zakir Thomas "Agricultural biotechnology and proprietary rights: challenges and policy options" (2006) 8 Journal of World Intellectual Property 711 at 718.

184 Clemente Forero-Pineda "The impact of stronger intellectual property rights on science and technology in developing countries" (2006) 35 Research Policy 808 at 818; Andrés Guadamuz González "Patented past, genetically modified future? Biotechnology and developing countries" Paper Available at ssrn.com [SSRN-id 1017827] at 9; Derek Byerlee \& Ken Fischer "Accessing modern science: policy and institutional options for agricultural biotechnology in developing countries" (2002) 30 World Development 931 at 934; John Barton "Research-tool patents: issues for health in the developing world" (2002) 80 Bulletin of the World Health Organization 821 at 823; Sergio Lence and Dermot Hayes "Welfare impacts of cross-country spillover in agricultural research" (2008) 90 American Journal of Agricultural Economics 197 at 204; Thomas (fn 183 above) at 719, 728; Carlos Correa \& Sisule Musungu "The WIPO patent agenda: the risks for developing countries" TRADE Working Paper 12 South Centre (2002) at 1920; May and Sell (fn 121 above) at 187-188; Amy Kapczynski et al "Addressing global health inequalities: an open licensing approach for university innovations" (2005) 20 Berkeley Technology Law Journal 1031 at 1084 .

185 For example, the merozoite surface protein 1 (MSP-1) of plasmodium shows promise for the development of a malaria vaccine. Use of this protein, however, is covered by no less than 39 patents which include "describing the antigen, processing fragments, constructs, production [and] delivery", and these belong to different patent holders. "This complex landscape requires the lengthy negotiation of multiple licenses, at an unpredictable cost": Correa and Musungu (fn 184 above) at 20.

186 See for example, Nancy Gallini \& Suzanne Scotchmer "Intellectual property: when is it the best incentive system?" University of California at Berkeley. Economics Working Papers E01-303 (2001) at 57; Richard Gilbert \& Carl Shapiro "Optimal patent length and breadth" (1990) 21 RAND Journal of Economics 106. See also the overviews of studies in Gifford (fn 10 above) ; David Encaoua, Dominique Guellec \& Catalina Martínez "Patent systems for encouraging innovation: lessons from economic analysis" (2006) 35 Research Policy 1423; Merges and Nelson (fn 13 above); Adam Jaffe "The US patent system in transition: policy innovation and the innovation process" (2000) 29 Research Policy 531.

187 See Merges \& Nelson (fn 13 above) for a broad overview; and the specific studies referred to in footnote 186 above.

188 See for example Nancy Gallini "The Economics of patents: lessons from recent US patent reform" (2002) 16 Journal of Economic Perspectives 131. 
have different impacts in different industries and in different economic contexts. ${ }^{189}$ It is impossible to develop a general model or template of "ideal protection levels" for any industry in any country.

Developed states have also consistently argued that if developing countries raise their levels of IP protection, they will attract foreign direct investment and technology transfer and will stimulate local innovation. ${ }^{190}$ However, in-depth theoretical economic analyses as well as consideration of empirical data tend to suggest that, while raising intellectual property standards has had demonstrably negative effects on public welfare in developing countries, ${ }^{191}$ it has not attracted the promised investment and technology transfer ${ }^{192}$ and seldom seems to increase levels of local innovation. ${ }^{193}$ Indeed, raised IP protection levels often have negative impacts on local innovation in developing states because many of the research inputs, upon which follow-on research is based, are subject to IP restrictions that make them unaffordable in these economies. ${ }^{194}$

${ }^{189}$ Robert Mazzoleni \& Richard Nelson "The benefits and costs of strong patent protection: a contribution to the current debate" (1998) 27 Research Policy 273.

${ }^{190}$ See for example, United States. Suggestion by the United States for Achieving the Negotiating Objective MTN.GNG/NG11/W/14 October 1987 at 1.

191 Maskus \& Reichman (fn 19 above) at 4.

192 International technology transfer can be defined as the "shifting of information across borders" and "its effective diffusion into recipient economies", including, for example, the sale of foreign-made goods, local manufacture of foreign products under licence, foreign direct investment in the form of production plants, and technical assistance (Maskus \& Reichman (fn 19 above) at 11). See also Carlos Primo Braga \& Carsten Fink "Relationship between intellectual property rights and foreign direct investment" (19981999) 9 Duke Journal of Comparative \& International Law 163 at 167; Carlos Correa "Can the TRIPS Agreement foster technology transfer to developing countries?" in Maskus \& Reichman (fn 19 above) at 229.

193 The United Kingdom CIPR has concluded that "in most low income countries, with a weak scientific and technological infrastructure, IP protection at the levels mandated by TRIPS is not a significant determinant of growth. On the contrary, rapid growth is more often associated with weaker IP protection. In technologically advanced developing countries, there is some evidence that IP protection becomes important at a stage of development, but that stage is not until a country is well into the category of middle income developing countries." (CIPR fn 40 above) at 26). See also Primo Braga \& Fink (fn 192 above) at 167; Elhanan Helpman 'Innovation, imitation and intellectual property rights' 61 Econometrica 1247 generally; Pedro Roffe "Technology transfer on the international agenda" in Maskus \& Reichman (fn 19 above) at 261; Patricia Schneider "International trade, economic growth and intellectual property rights: a panel data study of developed and developing countries" (2005) 78 Journal of Development Economics 529 at 539; Walter Park \& Juan Ginarte "Intellectual property rights and economic growth" (1997) 15(3) Contemporary Economic Policy 51 generally; Samuel Kortum "TRIPS and technology transfer: evidence from patent data" in Maskus and Reichman (fn 19 above) at 287; Sanjaya Lall "Indicators of the relative importance of IPRs in developing countries" (2003) 32 Research Policy 1657 at 1679; Amy Glass \& Kamal Saggi "Intellectual property rights and foreign direct investment" (2002) 56 Journal of International Economics 387 at 408; Jean-Eric Aubert "Promoting innovation in developing countries: a conceptual framework" (2005) World Bank Policy Research Working Paper 3554. Available at http://www-wds.worldbank.org/ (last visited May 2009) generally; Beata Smarzynska The composition of foreign direct investment and protection of intellectual property rights' (2004) World Bank Policy Research Working Paper 2786 (Available at http://www-wds.worldbank.org/ (visited May 2009) generally.

194 Correa (fn 192 above) at 231-232; Maskus \& Reichman (fn 19 above)' at 7, see also Kamal Saggi "Trade, foreign direct investment and international technology transfer: a survey" (2000) World Bank Policy Research Working Paper 3305 (Available at http://www-wds.worldbank.org/ (visited May 2009) at 35 , citing studies which conclude that stronger IPRs are not in the interests of southern states because they make it more difficult to reverse engineer and imitate foreign technologies. 


\subsection{Internal arguments at the Development Agenda discussions}

One of the most notable features of the Development Agenda discussions ${ }^{195}$ was the apparent consensus among all parties - both developed states and the GFD - on the "importance of development". What was also notable, however, was that no-one ever defined "development" explicitly - perhaps deliberately. ${ }^{196}$ A look at the priorities identified by each group and the policies they advocated, however, suggests that they had in mind somewhat different conceptions of development. Developed countries appeared to view macroeconomic development as the end goal. ${ }^{197}$ Their focus was on growing the economy generally by promoting local innovation and expanding international trade. ${ }^{198}$ Their arguments were consistently based on the assumption that intellectual property protection fostered innovation and technological development and that strengthening this protection would further promote these processes. ${ }^{199}$

From this perspective, increasing the levels of IP protection is an inherently prodevelopment activity. The United States, for example, stressed "the important role that intellectual property protection played in fostering economic development", noted that WIPO's mission was "to promote the protection of intellectual property throughout the world", and concluded that "because strong intellectual property protection [is] a fundamental part of any nation's sound economic policies, by its very nature, WIPO's mission, as currently elaborated, promoted economic development".200

As outlined above, however, it is far from clear that strengthening patent protection in developing countries will promote local innovation or technological development. This point was made repeatedly by developing states during the discussions. In particular, developing countries noted that inflexible IP protection at too high a level was likely to impede innovation in developing states rather than promote it. ${ }^{201}$ In this regard, a

195 Minutes of these meetings are available at www.wipo.int. See for example IIM/1/6.

196 As noted by Plantey: "Often, one of the first tasks of negotiators nowadays is to agree on the terminology, its use and meaning": Alain Plantey International negotiation in the twenty-first century Routledge-Cavendish (2007) at 405.

197 See Margaret Chon "Intellectual property and the development divide" (2006) 27 Cardozo Law Review 2821 at $2831-2$.

198 This accords broadly with what Amartya Sen has described as a "narrower" view of development: "identifying development with the growth of gross national product, or with the rise in personal incomes, or with industrialization, or with technological advance, or with social modernization": Amartya Sen Development as freedom Oxford University Press (2001) at 3.

199 This approach was not new. Developing countries have used these arguments since the Uruguay Round TRIPS negotiations in the 1980s. See for example the American submission to that forum in 1987: United States Suggestion by the United States for achieving the negotiating objective GATT doc. MTN.GNG/NG11/W/14 October 1987.

200 PCDA 1/6 Prov 2 para 24.

${ }^{201}$ See Pakistan's comments at the April 2005 meeting, noting that the impact of IP protection on overall economic development must be assessed on a case-by-case basis "in relation to the actual development challenges that were faced by developing countries" rather than "in an abstract, rhetorical manner", and referring specifically to the "often-constraining effects of IP on access to technology and countries' ability to innovate and compete", pointing out that "access to technology had become difficult in the face of broad patents, lengthened duration of protection, insufficient disclosures, patent pools with anticompetitive effects and skewed licensing conditions. These, and other mechanisms, were hardly 
number of developing countries specifically noted the importance of access to patented research tools in the development of local science and technology sectors and in the development of therapies for neglected diseases such as malaria and tuberculosis. ${ }^{202}$

Although developing countries repeatedly stressed these points, the developed states clung fast to their "absolute truth"203 that increased IP protection levels lead to development. During the April 2005 session, for example, the United States delegation "welcomed the opportunity" to discuss "the important role intellectual property played in fostering economic, social and cultural development". 204 The US delegation believed that development was "one of the most important challenges facing the international community" and that "intellectual property protection played a key and positive role in development". 205

Because they believed that protecting intellectual property is essential for promoting development, developed countries believed that WIPO already had a development agenda to be found precisely in its "contribution to the development of intellectual property" 206 and its efforts to ensure better and stronger intellectual property protection. Stronger and better intellectual property protection would itself promote "development of individuals and societies all across the globe". 207

The GFD demonstrated an entirely different understanding of development. From their perspective, development was something more than technological development, expansion of trade or macroeconomic growth. They stressed the importance of improvements in health, public welfare, nutrition and education, demonstrating an understanding of development as having an important human dimension. Its goal is improving the quality of life for everyone. ${ }^{208}$

While developing states did not expressly link their assertions to the development economics advanced by theorists such as Amartya Sen, their understanding of development can be broadly understood within Sen's framework "as a process of expanding the real freedoms that people enjoy ... [which include] the freedom to satisfy hunger, or to achieve sufficient nutrition, or to obtain remedies for treatable illnesses". ${ }^{209}$ For Sen, development is ultimately about the freedom to choose to live a worthwhile life. He has called this the "capabilities approach". "Human capabilities" refer to the "ability of

conducive to developing countries' endeavour to undertake research and development." (IIM/1/6 para 63). See also the comments made by South Africa (IIM/1/6 para 57); Peru (IIM/1/6 para 69); India (IIM/1/6 para 72); Venezuela (IIM/1/6 para 76); Kenya (IIM/1/6 para 81); Morocco (IIM/1/6 para 82); Argentina (IIM/1/6 para 94); Brazil (IIM/1/6 para 96); the African, Caribbean and Pacific Group of States (ACP) (IIM/1/6 para 110).

202 See for example Pakistan's comments (IIM/1/6 para 63).

203 cf GDF Proposal IIM/1/4 para 5.

204 IIM/1/6 para 36.

205 IIM/1/6 para 36. Similar assertions were made by other developed states, including the United Kingdom (for example para 38, noting that "the UK viewed the intellectual property system as a tool which could be used by society to progress both economically and technologically", but citing its own CIPR, which had a far more critical and nuanced approach to the matter.

206 Swiss Delegation IIM/1/6 para 59.

207 Italian Delegation IIM1/6 para 42.

208 See for example GDF Proposal IIM/1/4 paras 7 and 9.

209 Sen (fn 198 above) at 3-4. 
human beings to lead lives they have reason to value and to enhance the substantive choices they have". ${ }^{210}$ A person's ability and freedom to make these choices is enhanced when he or she is "healthy, well-nourished and educated". 211

The GFD referred consistently to health, nutrition, education and other aspects of development that enhance human capabilities and freedom. ${ }^{212}$ They emphasised the ways in which the international IP system prevents many people from accessing goods (such as pharmaceuticals) which have a direct bearing on their quality of life. For the GFD it is not enough that patents may encourage innovation; they stressed the importance of disseminating new inventions so that more people can enjoy their benefits. $^{213}$

No doubt, the United States and other developed countries agree that everyone should be fed, educated, and given medical treatment. In the WIPO Development discussions, however, they seemed to assume that these are probable by-products of the technological and macroeconomic growth that an intellectual property system will foster, rather than immediate goals of the system itself. They argued that higher levels of intellectual property protection would increase innovation and that economic growth would follow. $^{214}$ Their emphasis was on the ways in which the intellectual property system encourages the development of pharmaceutical, agricultural and other innovations, not on whether everyone is actually able to gain access to them.

Thus the consensus on "the importance of development" was ultimately something of an illusion. The parties were not really talking about the same thing. This was never spelled out. They did not debate their understandings of "development" but merely talked past one another, never engaging critically and pretending not to notice. ${ }^{215}$

\footnotetext{
${ }^{210}$ Amartya Sen "Human capital and human capability" (1997) 25 World Development 1959 at 1959.

211 Ibid.

212 These issues were raised by many developing country delegations at the April 2005 meeting; for example, Nigeria on behalf of the African group noting that "public interest considerations like education and health" should be considered when establishing an IP policy (IIM/1/6 para 56); Chile noting the importance of public health, the environment and education ( IIM/1/6 para 61); Pakistan noting the excessive pricing of development essentials such as pharmaceuticals and textbooks (IIM/1/6 para 63); Kenya noting the importance of "public health and social medicine" (IIM/1/6 para 81). Similar concerns were expressed by public interest NGOs (for example MSF IIM/1/6 para 129; Third World Network IIM/1/6 para 130) and by international organizations such as the WHO (IIM/1/6 para 109).
}

213 See comments by Nigeria IIM/1/6 para 56; Chile IIM/1/6 para 61; Pakistan, noting particularly the excessive on-patent price of pharmaceuticals IIM/1/6 para 63; Venezuela noting the right of all peoples to benefit from the progress flowing from science and technology IIM/1/6 para 76; South Africa IIM/1/6 para 57; Paraguay IIM/1/6 para 84; Cuba IIM/1/6 para 88; Argentina IIM/1/6 para 94; Egypt IIM/1/6 para 99. Similar concerns were expressed by public interest NGOs (for example MSF IIM/1/6 para 129; Third World Network IIM/1/6 para 130) and by the WHO (IIM/1/6 para 109). See also Robert Howse "Mainstreaming the right to development into international trade and policy at the World Health Organisation" Paper prepared for the UN Commission on Human Rights (E/CN.4/Sub.2./2004/17, 9 June 2004), available at http://www2.ohchr.org/english/issues/development/refdoc.htm (visited May 2010) para 15, arguing that the IP system should lead to enhancement of human capabilities.

${ }^{214}$ United States IIM/1/6 para 35.

215 Cf Christopher May "The World Intellectual Property Organisation and the Development Agenda" Paper presented at the conference Frontiers of Regulation: Assessing Scholarly Debates and Scholarly Challenges (University of Bath, 8 September 2006) at 7, referring to "these sorts of misunderstandings". 
Although the GFD may have intended its appeal to a "development dimension" as an "external argument" (particularly in light of explicit reference to the MDGs and other external documents), the goal of development is not external to the intellectual property regime or to the patent system: the public goods (medicines, food, education) that the GFD referred to in their conception of "development" have always been the intended products of the intellectual property system. ${ }^{216}$ In addition, "development", understood as macroeconomic growth, is a core goal of the intellectual property system for the developed states. Thus, in practice, the appeal to "development" was yet another "internal argument", easily co-opted by developed states which continued to present their own "internal" development arguments, allowing the discussions to go round in circles for years.

An explicit human rights-based approach, linked to precise and binding norms, could have helped focus developing states' demands and might have prevented this kind of circular non-engagement by pointing to clear, absolute, and non-negotiable bottom lines, less vulnerable to this kind of high-level and theoretical non-discussion.

For example, the developing states could have relied on the clear and well-developed benchmarks for the right to health. The Development Agenda discussions were about "development"; the UN Secretary General has described the HIV/AIDS pandemic as "our biggest development challenge". 217 In Africa, HIV/AIDS has been cited as both a result and a cause of endemic poverty. ${ }^{218}$ AIDS deaths are concentrated among adults of working age, potentially crippling the productive capacity of the economy and affecting states' capacity for economic development and technological innovation. ${ }^{219}$ Illness affects the productivity of businesses and manufacturing plants; among farm workers it lowers agricultural output and threatens food security. ${ }^{220}$ School enrolments drop significantly, which affects the future productive capabilities of the children and of the economy generally. ${ }^{221}$ The scale of the epidemic places enormous strain on health and welfare services, diverting funds from alternative development projects. ${ }^{222}$ The WHO's Commission on Macroeconomics and Health has concluded that "[ $t$ ] he AIDS pandemic represents a unique challenge of unprecedented urgency and intensity. This single epidemic can undermine Africa's development over the next generation ... unless addressed by greatly increased efforts".223

\footnotetext{
216 See the discussion on welfare enhancing narratives above.

${ }^{217}$ As quoted in Walker (fn 6 above) para 45.

${ }^{218}$ Jeffrey Sachs The end of poverty: how we can make it happen in our lifetime Penguin (2005) at 204; Alan Whiteside "Poverty and HIV/AIDS in Africa" (2002) 23 Third World Quarterly 313 generally.

${ }^{219}$ Nicoli Nattrass "Unemployment and AIDS: the social-democratic challenge for South Africa" (CSSR Working Paper no 41). University of Cape Town. Centre for Social Science Research (2003) at 4; Whiteside (fn 218 above) at 320-321; Walker (fn 6 above) para 45.

${ }^{220}$ Walker (fn 6 above) para 45.

${ }^{221}$ See Sachs (fn 218 above) at 198, 201; Roeland Monasch \& J Ties Boerma "Orphanhood and childcare patterns in sub-Saharan Africa: an analysis of national surveys from 40 countries" (2004) 18 AIDS S55 para 45.

${ }^{222}$ Helen Watchirs "A human rights approach to HIV/AIDS: transforming international obligations into national law" (2002) 22 Australian Yearbook of International Law 77 at 80-81; Sisule Musungu "The TRIPS Agreement and public health provisions" in Correa \& Yusuf (eds) Intellectual property and international trade: the TRIPS Agreement 2 ed. Wolters-Kluwer (2008) 421 at 424.
}

${ }^{223}$ WHO (fn 17 above) at 1-2. See also Sachs (fn 218 above) at 204. 
States urgently need access to affordable antiretroviral medicine to control the pandemic. ${ }^{224}$ The link between HIV/AIDS, development and essential medicines is clear. And the link between essential medicines, intellectual property and human rights has also now been clearly set out by the CESCR. Furthermore, development of new essential medicines to combat other diseases such as malaria and tuberculosis may be impeded by patenting of upstream research, also identified as a violation of the right to health.

If the developing countries had highlighted the HIV/AIDS pandemic as an urgent development concern, explained how patenting standards may impede the availability of essential medicines and raised the CESCR's human rights benchmarks, they would have focused the Development Agenda discussions on some of the specific ways in which IP promotes or impedes development, and could have suggested some practical (and perhaps legally required) solutions to current difficulties.

\section{MOVING FORWARD: WORKING WITH THE DEVELOPMENT AGENDA}

The Development Agenda was finally adopted in September 2007. The 45 agreed Recommendations call for a new approach to intellectual property: IP protection should be considered "in the context of broader societal interests and especially developmentoriented concerns" in accordance with Article 7 of the TRIPS Agreement, which is quoted in full. 225

The cluster of Recommendations most relevant to this paper's concern with policy flexibility is Cluster B on "norm-setting, flexibilities, public policy and the public domain". ${ }^{226}$ Recommendation 15 provides the following:

"Norm-setting activities shall:

- be inclusive and member-driven;

- take into account different levels of development;

- take into consideration a balance between costs and benefits;

- be a participatory process, which takes into consideration the interests and priorities of all WIPO Member States and the viewpoints of other stakeholders, including accredited inter-governmental organisations (IGOs) and NGOs; and

- be in line with the principle of neutrality of the WIPO Secretariat."227

These are extremely important recommendations, but lack specificity. There are no clear guidelines or benchmarks to assess whether intellectual property norm-setting achieves "a balance between costs and benefits" 228 or what it means to "take into account different levels of development". There are no clear bottom lines to resolve the cost-benefit tension inherent in the intellectual property system. Indeed, it is not clear either that the Recommendations offer any more guidance than TRIPS's existing flexibilities, or that they

${ }^{224}$ CIPR (fn 40 above); WHO (fn 112 above) para 17; DFID (fn 36 above) ; WHO (fn 41 above) at 238; Médecins sans Frontières (fn 112 above).

225 Recommendation 45.

226 Recommendations 15-23.

${ }^{227}$ Recommendation 15.

${ }^{228}$ Recommendation 15. 
will avert the circular debate that characterised the WIPO Development Agenda discussions and the Doha talks.

The closest the Recommendations come to providing a firm and non-negotiable bottom line is Recommendation 22, which provides that "WIPO's norm-setting activities should be supportive of the development goals agreed within the United Nations System, including those contained in the Millennium Development Goals".229

The MDGs provide a list of universally-agreed ${ }^{230}$ priorities which, in terms of Recommendation 22, intellectual property rules should promote rather than obstruct. The Goals provide possible benchmarks against which proposed IP treaties can be assessed. For example, promotion of MDG 6 to "[a]chieve, by 2010, universal access to treatment for HIV/AIDS for all those who need it"231 might suggest that states should have enough patent policy flexibility to establish pharmaceutical strategies which include generic medicines. However, MDG 8, to the effect that states should "[i]n cooperation with pharmaceutical companies, provide access to affordable essential drugs in developing countries", 232 could undermine this conclusion by suggesting that the goal of universal access might be achieved through voluntary donations or discounts from pharmaceutical companies or through developing states' increased buying-power resulting from other parts of MDG 8 such as grants, debt relief and enhanced export opportunities. $^{233}$ These are precisely the types of solutions that developed states have previously preferred to more flexible IP rules. ${ }^{234}$

It appears that the MDGs are not specific enough to "counter" the detailed rules in TRIPS: they do not mandate clear routes to their achievement and are open to a variety of interpretations. Human rights norms provide many advantages over the policy references in the MDGs or the Development Agenda more broadly. In contrast to policy references, as noted already, human rights standards provide "specific limitations on what is negotiable, and lay down precise minimum conditions which are beyond negotiation". ${ }^{235}$

However, the MDGs and the broader reference to "development goals agreed within the United Nations System" could yet be used to introduce an explicit human rights focus to IP discussions. It is a question of how UN development goals are interpreted ${ }^{236}$ In recent years the United Nations has adopted an explicitly "rights-based approach to development", defined as "a conceptual framework for the process of human development that is normatively based on international human rights standards and operationally directed to promoting and protecting human rights". 237 There are many benefits to

\footnotetext{
229 Recommendation 22.

230 The MDGs were adopted unanimously by the UN General Assembly.

231 Part of MDG 6: see http://www.un.org/millenniumgoals (visited December 2010).

232 Part of MDG 8.

233 MDG 8.

234 See the EC and American Delegations' comments at the Doha talks for example [IP/C/M/31]

235 Darrow (fn 142 above) at 5.

236 See Philip Alston "Ships passing in the night: the current state of the human rights and development debate seen through the lens of the Millennium Development Goals" (2005) 27 Human Rights Quarterly 755 for an interpretation of the MDGs in light of the ICESCR.

237 High Commission on Human Rights 'What is a rights-based approach to development?' at http://www.unhchr.ch/development/approaches-04.html (last visited December 2007); CESCR General
} 
linking "development" to the norms set out in international human rights documents; key among them is that human rights norms are specific, measurable, often binding, and have already been formally adopted by most states. Furthermore, the human rights system focuses attention on the needs of the poor, thus promoting an understanding of "development" which is directed at improving the quality of life for everyone and at increasing human capabilities and freedom.

Since the adoption of the Development Agenda, human rights agencies within the United Nations have offered to assist WIPO in the interpretation of the "development orientated" norm-setting referred to in the Agenda. The UN Working Group on the Right to Development, for example, has met with WIPO to highlight the importance of ensuring that intellectual property rules are human rights-compliant and that Development Agenda work is informed by a human rights approach. ${ }^{238}$

If states want to move their discussion forward in a meaningful way they should examine the contributions made by human rights bodies such as the CESCR and the Working Group on the Right to Development. The human rights system offers standards and benchmarks that give legal content to the term "public benefit", against which the social costs of the intellectual property system can be assessed. Unlike the intellectual property system, the human rights system provides objective bottom lines.

The WIPO Development Agenda does not in itself offer any new guidelines or benchmarks that provide a "paradigm shift"239 for future discussions. However, the human rights community is willing to assist with interpretation of the Agenda document (and the UN development goals to which it refers), so as to insert human rights norms into the conversation. All WIPO states should take advantage of this opportunity so that intellectual property can indeed become a constructive tool for the betterment of human existence. $^{240}$

Comment 2 international technical assistance measures (Article 22 of the Covenant) (contained in E/1990/23).

238 Working Group on the Right to Development Report of the high-level task force on the implementation of the right to development on its sixth session (February 2010) A/HRC/15/WG.2/TF/2.

${ }^{239} \mathrm{Cf}$ Statement by Egypt on behalf of the Development Action Group, presented at the $5^{\text {th }}$ Session of the CDIP, 26-30 April, 2010.

240 Cf Delegate from Ecuador at the WIPO Development Agenda discussions June 29, 2006 quoted in footnote 1 . 


\section{BIBLIOGRAPHY}

Abbott, Frederick "TRIPS and human rights: preliminary reflections" in Abbott, BreiningKaufmann \& Cottier (eds) International trade and human rights: foundations and conceptual issues University of Michigan Press (2006) 14.

Abbott, Frederick \& Jerome Reichman “The Doha Round's public health legacy: strategies for the production and diffusion of patented medicines under the amended TRIPS provisions" 10 Journal of International Economic Law 921.

Alston, Philip "Out of the abyss: the challenges confronting the new U.N. Committee on Economic, Social and Cultural Rights" (1987) 9 Human Rights Quarterly 332.

Alston, Philip "Ships passing in the night: the current state of the human rights and development debate seen through the lens of the Millennium Development Goals" (2005) 27 Human Rights Quarterly 755.

Alston, Philip \& Gerard Quinn “The nature and scope of states parties' obligations under the International Covenant on Economic, Social and Cultural Rights" (1987) 9 Human Rights Quarterly 156.

Alvarez, José "How not to link: institutional conundrums of an expanded trade regime" (2001) 7 Widener Law Symposium Journal 1.

Arrow, Kenneth "Economic welfare and the allocation of resources for invention" in Rosenberg (ed) The economics of technological change Penguin (1971).

Aubert, Jean-Eric "Promoting innovation in developing countries: a conceptual framework" (2005) World Bank Policy Research Working Paper 3554. Available from http://www-wds.worldbank.org/ (last visited May 2009).

Bae, Sangmin When the state no longer kills: international human rights norms and the abolition of capital punishment State University of New York Press, (2007).

Bainbridge, David Intellectual property 4 ed Pearson Education (1999).

Baker, Brook "Arthritic flexibilities for accessing medicines: analysis of WTO action regarding Paragraph 6 of the Doha Declaration on the TRIPS Agreement and Public Health" (2004) 14 Indiana International and Comparative Law Review 613.

Barton, John "Issues posed by a world patent system" in Maskus and Reichman (eds) International public goods and transfer of technology under a globalized intellectual property regime Cambridge University Press (2005) 617.

Barton, John "Research-tool patents: issues for health in the developing world" (2002) 80 Bulletin of the World Health Organization 821.

Berger, Jonathan "The global AIDS crisis: tripping over patents: AIDS, access to treatment and the manufacturing of scarcity" (2002) 17 Connecticut Journal of International Law 157.

Berman, Helen \& Rochelle Dreyfuss "Reflections on the science and law of structural biology, genomics, and drug development" (2006) 53 UCLA Law Review 871. 
Burk, Dan and Mark Lemley "Policy levers in patent law" (2003) 89 Virginia Law Review 1575.

Byerlee, Derek \& Ken Fischer "Accessing modern science: policy and institutional options for agricultural biotechnology in developing countries" (2002) 30 World Development 931.

Campbell, Eric et al "Data withholding in academic medicine: characteristics of faculty denied access to research results and biomaterials" (2000) 29 Research Policy 303.

Cann, Wesley "On the relationship between intellectual property rights and the need of less-developed countries for access to pharmaceuticals: creating a legal duty to supply under a theory of progressive global constitutionalism" (2004) 25 University of Pennsylvania Journal of International Economic Law 755.

Cassel, Douglass “Does international human rights law make a difference?'”(2001) 2 Chicago Journal of International Law 121.

Chapman, Audrey “A 'violations approach' for monitoring the International Covenant on Economic, Social and Cultural Rights" (1996) 18 Human Rights Quarterly 23.

Chapman, Audrey "Core obligations related to the right to health and their relevance for South Africa" in Brand and Russell (eds) Exploring the core content of socio-economic rights: South African and international perspectives Protea Book House (2002) 35.

Chayes, Abram \& Antonia Chayes “On compliance" (1993) 47 International Organization 175.

Checkel, Jeffrey "Why comply? Social learning and European identity change" (2001) 55 International Organization 553.

Chirwa, Danwood "The right to health in international law: its implications for the obligations of state and non-state actors in ensuring access to medicine" (2003) 19 SAJHR 541.

Chon, Margaret "Intellectual property and the development divide" (2006) 27 Cardozo Law Review 2821.

Cornish, William Intellectual property: patents, copyrights, trade marks and allied rights 4 ed Sweet \& Maxwell (1999).

Correa, Carlos "Can the TRIPS Agreement foster technology transfer to developing countries?" in Maskus and Reichman (eds) International public goods and transfer of technology under a globalized intellectual property regime Cambridge University Press (2005) 227.

Correa, Carlos "Implications of the Doha Declaration on the TRIPS Agreement and Public Health" Health Economics and Drugs EMD Series no 12 World Health Organization (2002). Available from www.who.int (last visited August 2010).

Correa, Carlos "Patent rights' provisions" in Correa and Yusuf (eds) Intellectual property and international trade: the TRIPS Agreement 2 ed. Wolters-Kluwer (2008) 227.

Correa, Carlos \& Sisule Musungu "The WIPO patent agenda: the risks for developing countries" TRADE Working Paper 12 South Centre (2002). 
Cottier, Thomas "The Doha Waiver and its effects on the nature of the TRIPS system and on competition law: the impact of human rights" in Govaere \& Ullrich (eds) Intellectual property, public policy and international trade (Peter Lang (2007) 173.

Craven, Matthew The International Covenant on Economic, Social and Cultural Rights: a perspective on its development Clarendon Press (1995).

Cronin, Bruce "The paradox of hegemony: America's ambiguous relationship with the United Nations" (2001) 7 European Journal of International Relations 103.

Danzon, Patricia \& Adrian Towse "Theory and implementation of differential pricing for pharmaceuticals" in Maskus \& Reichman (eds) International public goods and transfer of technology under a globalized intellectual property regime Cambridge University Press (2005) 425.

Darrow, Mac Between light and shadow: the World Bank, the International Monetary Fund and international human rights law Hart (2003).

Drahos, Peter "Developing countries and international intellectual property standardsetting" (2002) 5 Journal of World Intellectual Property 765.

Drahos, Peter Death of patents Lawtext Publishing and Queen Mary Intellectual Property Research Institute (2005).

Drahos, Peter with John Braithwaite Information feudalism: who owns the knowledge economy? Earthscan (2002).

Drommen, Caroline "Safeguarding the legitimacy of the multilateral trading system: the role of human rights law" in Abbott, Breining-Kaufmann \& Cottier (eds) International trade and human rights: foundations and conceptual issues University of Michigan Press (2006) 121.

Dutfield, Graham \& Uma Suthersanen "The innovation dilemma: intellectual property and the historical legacy of cumulative creativity" (2004) 4 Intellectual Property Quarterly 379.

Eckersley, Robyn "Soft law, hard politics, and the Climate Change Treaty" in Reus-Smit (ed) The politics of international law Cambridge University Press (2004) 80.

Eide, Asbjørn, Catarina Krause \& Allan Rosas (eds) Economic, social and cultural rights: a textbook 2 rev. ed. Martinus Nijhoff (2001).

Eisenberg, Rebecca "Bargaining over the transfer of proprietary research tools: is the market failing or emerging?" in Cooper, Zimmerman \& First (eds) Expanding the boundaries of intellectual property law: innovation policy for the knowledge society Oxford University Press (2001) 223.

Encaoua, David, Dominique Guellec \& Catalina Martínez "Patent systems for encouraging innovation: lessons from economic analysis" (2006) 35 Research Policy 1423.

Falk, Richard "Taking human rights seriously at home” (1997) 68 Political Quarterly 179.

Farmer, Paul with Nicole Gastineau "Legal and human rights intervention for health: rethinking health and human rights: time for a paradigm shift" 30 Journal of Law, Medicine \& Ethics 655. 
Fink, Carsten "International price discrimination and market segmentation for patented pharmaceuticals in the EU: a social welfare analysis" in Govaere and Ullrich (eds) Intellectual property, public policy and international trade Peter Lang (2007) 169.

Foot, Rosemary Rights beyond borders: the global community and the struggle over human rights in China Oxford University Press (2000).

Forero-Pineda, Clemente "The impact of stronger intellectual property rights on science and technology in developing countries" (2006) 35 Research Policy 808.

Gallini, Nancy "The Economics of patents: lessons from recent US patent reform" (2002) 16 Journal of Economic Perspectives 131.

Gallini, Nancy \& Suzanne Scotchmer "Intellectual property: when is it the best incentive system?" University of California at Berkeley. Economics Working Papers E01-303 (2001).

Geuna, Aldo \& Lionel Nesta "University patenting and its effects on academic research: the emerging European evidence" (2006) 35 Research Policy 790.

Gifford, Daniel "How do the social benefits and costs of the patent system stack up in pharmaceuticals?" (2004) 12 Journal of Intellectual Property Law 75.

Gilbert, Richard \& Carl Shapiro "Optimal patent length and breadth" (1990) 21 RAND Journal of Economics 106.

Glass, Amy \& Kamal Saggi "Intellectual property rights and foreign direct investment" (2002) 56 Journal of International Economics 387.

González, Andrés Guadamuz "Patented past, genetically modified future? Biotechnology and developing countries" Paper available from ssrn.com [SSRN-id 1017827].

Goodman, Ryan \& Derek Jinks "How to influence states: socialization and international human rights law" (2004) 54 Duke Law Journal 621.

Gross, Aeyal "The right to health in an era of privatisation and globalisation: national and international perspectives" in Barak-Erez and Gross (eds) Exploring social rights: between theory and practice Hart (2007).

Grover, Anand The right of everyone to the enjoyment of the highest attainable standard of physical and mental health: report of the Special Rapporteur' (A/HRC/11/12 (2009).

Gupta, Amit "Patent rights on pharmaceutical products and affordable drugs: can TRIPS provide a solution?" (2004) 2 Buffalo Intellectual Property Law Journal 127.

Harrison, James The human rights impact of the World Trade Organisation Hart (2007).

Hassim, Adila, Mark Heywood, Jonathan Berger Health \& democracy: a guide to human rights, health law and policy in post-apartheid South Africa SiberInk (2007).

Haugen, Hans “General Comment No 17 on 'authors' rights"' (2007) 10 Journal of World Intellectual Property 53.

Haugen, Hans The right to food and the TRIPS Agreement Nijhoff (2007). 
Helfer, Lawrence "Regime shifting: the TRIPS Agreement and new dynamics of international intellectual property law making" (2004) 29 Yale Journal of International Law 1.

Helfer, Lawrence "Toward a human rights framework for intellectual property" (2007) 40 UC Davis Law Review 971.

Helfer, Lawrence and Anne-Marie Slaughter "Toward a theory of effective supranational adjudication" (1997) 107 Yale Law Journal 273.

Heller, Michael \& Rebecca Eisenberg "Can patents deter innovation? The anticommons in biomedical research" (1998) 280 Science 698.

Helpman, Elhanan 'Innovation, imitation and intellectual property rights' 61 Econometrica 1247.

Heywood, Mark "Drug access, patents and global health: 'chaffed and waxed sufficient'” (2002) 23 Third World Quarterly 217.

Holman, Christopher "Do reverse payment settlements violate the antitrust law?" (2007) 23 Santa Clara Computer \& High Technology Law Journal 489.

Howse, Robert "Mainstreaming the right to development into international trade and policy at the World Health Organisation" Paper prepared for the UN Commission on Human Rights (E/CN.4/Sub.2./2004/17, 9 June 2004). Available from http://www2.ohchr.org/english/issues/development/refdoc.htm (visited May 2010).

Howse, Robert and Makau Mutua "Protecting human rights in a global economy: challenges for the World Trade Organization" (2000). Available at www.ichrdd.ca/ english/commdoc/publications/globalization/wtoRightsGlob.html ((visited December 2010).

Hunt, Paul Reclaiming social rights: international and comparative perspectives Ashgate (1996).

Hunt, Paul The right of everyone to the enjoyment of the highest attainable standard of physical and mental health: report of the Special Rapporteur' (UN Doc E/CN.4/2004/49/Add.1 (2004).

International Law Commission Fragmentation of international law: difficulties arising from the diversification and expansion of international law. Final report of the Study Group of the International Law Commission, finalized by Martti Koskenniemi. UN Doc A/CN.4/L/682 (13 April 2006). Available from http://www.un.org/law/ilc/index.htm (last visited March 2008).

Jaffe, Adam "The US patent system in transition: policy innovation and the innovation process" (2000) 29 Research Policy 531.

Johnstone, Ian "The power of interpretive communities" in Barnett and Duvall (eds) Power in global governance Cambridge University Press (2005) 187.

Kapczynski, Amy et al "Addressing global health inequalities: an open licensing approach for university innovations" (2005) 20 Berkeley Technology Law Journal 1031.

Kaplow, Louis "The patent-antitrust intersection: a reappraisal" (1984) 97 Harvard Law Review 1813. 
Koh, Harold “Why do nations obey international law?” (1997) 106 Yale Law Journal 2599.

Kortum, Samuel "TRIPS and technology transfer: evidence from patent data" in Maskus and Reichman (eds) International public goods and transfer of technology under a globalized intellectual property regime Cambridge University Press (2005) 282.

Lall, Sanjaya "Indicators of the relative importance of IPRs in developing countries" (2003) 32 Research Policy 1657.

Landes, William \& Richard Posner The economic structure of intellectual property law Harvard University Press (2003).

Leckie, Scott "Another step toward indivisibility: identifying the key features of violations of economic, social and cultural rights" (1998) 20 Human Rights Quarterly 81.

Lehmann, Karin "In defense of the Constitutional Court: litigating socio-economic rights and the myth of the minimum core" (2006) 22 American University International Law Review 163.

Lence, Sergio \& Dermot Hayes "Welfare impacts of cross-country spillover in agricultural research" (2008) 90 American Journal of Agricultural Economics 197.

Machlup, Fritz \& Edith Penrose "The patent controversy in the nineteenth century" (1950) 10 Journal of Economic History 1.

Marceau, Gabrielle "The WTO dispute settlement and human rights" in Abbott, BreiningKaufmann \& Cottier (eds) International trade and human rights: foundations and conceptual issues University of Michigan Press (2006) 181.

Maskus, Keith \& Jerome H Reichman (eds) International public goods and transfer of technology under a globalized intellectual property regime Cambridge University Press (2005).

May, Christopher "The World Intellectual Property Organisation and the Development Agenda" Paper presented at the conference Frontiers of Regulation: Assessing Scholarly Debates and Scholarly Challenges (University of Bath, September $8^{\text {th }}, 2006$ ).

May, Christopher \& Susan Sell Intellectual property rights: a critical history Lynne Rienner (2006).

Mazzoleni, Robert \& Richard Nelson "The benefits and costs of strong patent protection: a contribution to the current debate" (1998) 27 Research Policy 273.

Médecins sans Frontières "A matter of life and death: the role of patents in access to essential medicines: MSF Briefing Document for the $4^{\text {th }}$ WTO Ministerial Conference in Doha, Qatar, November 9-13, 2001" 2001 MSF Article. Available at www.msf.org (last visited August 2010).

Médecins sans Frontières "Amendment to WTO TRIPS agreement makes access to affordable medicines even more bleak" 2005 MSF Article. Available at www.msf.org (last visited April 2010).

Médecins sans Frontières Untangling the web of price reductions: a pricing guide for the purchase of ARVs for developing countries 11 ed Médecins sans Frontières (2008). 
Merges, Robert \& Jane Ginsburg Foundations of intellectual property Foundation Press (2004).

Merges, Robert \& Richard Nelson “On the complex economics of patent scope” (1990) 90 Columbia Law Review 839.

Monasch, Roeland \& J Ties Boerma "Orphanhood and childcare patterns in sub-Saharan Africa: an analysis of national surveys from 40 countries" (2004) 18 AIDS S55.

Musungu, Sisule "The TRIPS Agreement and public health provisions" in Correa and Yusuf (eds) Intellectual property and international trade: the TRIPS Agreement 2 ed. Wolters-Kluwer (2008) 421.

Musungu, Sisule \& Graham Dutfield "Multilateral agreements and a TRIPS-plus world: the World Intellectual Property Organisation (WIPO)” (2003) TRIPS issues papers 3. Available from www.geneva.quno.info. (Last visisted August 2010).

Narula, Smita "The right to food: holding global actors accountable under international law" (2006) 44 Columbia Journal of Transnational Law 691.

Nattrass, Nicoli "Unemployment and AIDS: the social-democratic challenge for South Africa" (CSSR Working Paper no 41). University of Cape Town. Centre for Social Science Research (2003).

Okediji, Ruth "Narratives of developing country participation in the global intellectual property system" (2003) 7 Singapore Journal of International and Comparative Law 315.

Ovett, Davinia "Making trade policies more accountable and human-rights consistent: a NGO perspective of using human rights instruments in the case of access to medicines" in Benedek, de Feyter \& Marrella (eds) Economic globalisation and human rights Cambridge University Press (2007) 170.

Park, Walter \& Juan Ginarte "Intellectual property rights and economic growth" (1997) 15(3) Contemporary Economic Policy 51.

Pauwelyn, Joost Conflict of norms in public international law: how WTO law relates to other rules of international law Cambridge University Press (2003).

Plantey, Alain International negotiation in the twenty-first century Routledge-Cavendish (2007).

Pogge, Thomas "Human rights and global health: a research program" (2005) 36 Metaphilosophy 182.

Primo Braga, Carlos \& Carsten Fink 'Relationship between intellectual property rights and foreign direct investment (1998-1999) 9 Duke Journal of Comparative \& International Law 163.

Ragavan, Srividhya "Of the inequals of the Uruguay Round" (2006) 10 Marquette Intellectual Property Law Review 273.

Rai, Arti "The information revolution reaches pharmaceuticals: balancing innovation incentives, cost, and access in the post-genomics era" 2001 University Illinois Law Review 173. 
Risse, Thomas, Stephen Ropp \& Kathryn Sikkink (eds) The power of human rights: international norms and domestic change Cambridge University Press (1999).

Robinson, Mary "What rights can add to good development practice" in Alston and Robinson (eds) Human rights and development: towards mutual reinforcement Oxford University Press (2005) 25.

Roffe, Pedro "Technology transfer on the international agenda" in Maskus and Reichman (eds) International public goods and transfer of technology under a globalized intellectual property regime Cambridge University Press (2005) 257.

Runge, C Ford \& Edi Defrancesco "Exclusion, inclusion, and enclosure: historical commons and modern intellectual property" (2006) 34 World Development 1713.

Russell, Sage "Minimum state obligations: international dimensions" in Brand \& Russell (eds) Exploring the core content of socio-economic rights: South African and international perspectives Protea Book House (2002) 11.

Sachs, Jeffrey The end of poverty: how we can make it happen in our lifetime Penguin (2005).

Saez, Catherine "Drug access waiver debate looms for June TRIPS Council Meeting" Intellectual Property Watch Archive. Available at http://www.ipwatch.org/weblog/archives/ (last visited June 2010).

Saggi, Kamal "Trade, foreign direct investment and international technology transfer: a survey" (2000) World Bank Policy Research Working Paper 3305. Available from http://www-wds.worldbank.org/ (visited May 2009).

Sajo, Andras “Socioeconomic rights and the international economic order' (2002) 35 New York University Journal of International Law \& Policy 221.

Scheinin, Martin "Economic and social rights as legal rights" in Eide, Krause and Rosas (eds) Economic, social and cultural rights: a textbook 2 rev. ed. Martinus Nijhoff (2001) 29.

Schneider, Patricia "International trade, economic growth and intellectual property rights: a panel data study of developed and developing countries" (2005) 78 Journal of Development Economics 529.

Scotchmer, Suzanne "Standing on the shoulders of giants: cumulative research and the patent law" (1991) 5 Journal of Economic Perspectives 29.

Sell, Susan "TRIPS and the Access to Medicines Campaign" (2002) 20 Wisconsin International Law Journal 481.

Sell, Susan Private power, public law: the globalization of intellectual property rights Cambridge University Press (2003).

Sen, Amartya "Human capital and human capability” (1997) 25 World Development 1959.

Sen, Amartya Development as freedom Oxford University Press (2001).

Sepúlveda, Magdalena The nature of the obligations under the International Covenant on Economic, Social and Cultural Rights Intersentia (2003). 
Seuba, Xavier "Human rights and intellectual property rights provisions" in Correa \& Yusuf (eds) intellectual property and international trade: the TRIPS Agreement 2 ed. Wolters-Kluwer (2008) 387.

Shany, Yuval "Stuck in a moment in time: the international justiciability of economic, social and cultural rights" in Barak-Erez \& Gross (eds) Exploring social rights: between theory and practice Hart (2007) 77.

Sherman, Brad \& Lionel Bently The making of modern intellectual property law Cambridge University Press (1999).

Slaughter, Anne-Marie A new world order Princeton University Press (2005).

Smarzynska, Beata The composition of foreign direct investment and protection of intellectual property rights' (2004) World Bank Policy Research Working Paper 2786. Available from http://www-wds.worldbank.org/ (visited May 2009).

Steiner, Henry \& Philip Alston (eds) International human rights in context: law, politics, morals Oxford University Press (2000).

Thomas, Caroline "Trade policy and the politics of access to drugs" (2002) 23 Third World Quarterly 251.

Thomas, Zakir "Agricultural biotechnology and proprietary rights: challenges and policy options" (2006) 8 Journal of World Intellectual Property 711.

Thumm, Nikolaus "Patents for genetic inventions: a tool to promote technological advance or a limitation for upstream inventions?" (2005) 25 Technovation 1410.

UNCTAD-ICTSD Resource book on TRIPS and development Cambridge University Press (2005).

United Kingdom. Commission on Intellectual Property Rights Integrating Intellectual Property Rights and Development Policy: Report of the Commission on Intellectual Property Rights United Kingdom. Commission on Intellectual Property Rights (2002). Available from http://www.iprcommission.org (last visited August 2010).

United Kingdom. Department for International Development Increasing people's access to essential medicines in developing countries: a framework for good practice in the pharmaceutical industry DFID (2005).

United States. National Institute of Health. Working Groups on Research Tools. Report of the National Institute of Health (NIH) Working Group on Research Tools. Presented by the Advisory Committee to the Director, June 4, 1998. Available from http://www.nih.gov/news/researchtools/ (visited December 2010)

Wai, Robert "Countering, branding, dealing: using economic and social rights in and around the international trade regime" (2003) 14 European Journal of International Law 35.

Walker, Simon "A human rights approach to the WTO's TRIPS Agreement" in Abbott, Breining-Kaufmann \& Cottier (eds) International trade and human rights: foundations and conceptual issues University of Michigan Press (2006) 171.

Walker, Simon The Impact of the Agreement on Trade-Related Aspects of Intellectual Property Rights on Human Rights: Report of the High Commissioner, ECOSOC 
(Commission on Human Rights, Sub-Commission on the Promotion and Protection of Human Rights, $52^{\text {nd }}$ Session, Provisional Agenda item 4. UN Doc E/CN.4/Sub.2/2001/13 (2001) (27 July 2001).

Watal, Jayashree "Background note for the Workshop on Differential Pricing and Financing of Essential Drugs". Available at http://www.wto.org/english/ tratop e/trips e/wto background e.doc (last visited August 2010).

Watal, Jayashree Intellectual property rights in the WTO and developing countries Kluwer Law International (2001).

Watchirs, Helen "A human rights approach to HIV/AIDS: transforming international obligations into national law" (2002) 22 Australian Yearbook of International Law 77.

Weissbrodt, David \& Connie de la Vega International human rights law: an introduction University of Pennsylvania Press (2007).

Weissbrodt, David \& Kell Schoff "Human rights approach to intellectual property protection: the genesis and application of Sub-Commission Resolution 2000/7" (2003) 5 Minnesota Intellectual Property Law Review 1.

Whiteside, Alan "Poverty and HIV/AIDS in Africa" (2002) 23 Third World Quarterly 313.

Yamin, Alicia "Not just a tragedy: access to medications as a right under international law" (2003) 21 Boston University International Law Journal 325.

\section{United Nations Committee on Economic, Social and Cultural Rights (CESCR) documents}

(available at http://www2.ohchr.org/english/bodies/cescr/comments.htm)

General Comment No 2: international technical assistance measures (Article 22 of the Covenant) (contained in E/1990/23) (May 1990) [CESCR General Comment 2].

General Comment No 3: The nature of states parties' obligations (UN Doc E/1991/23, adopted Dec 1990). [CESCR General Comment 3].

General comment 14: The right to the highest attainable standard of health (Article 12) (UN Doc E/C.12/2000/4). [CESCR General Comment 14].

\section{World Health Organization documents}

(available at www.who.int)

World Health Organization "Access to medicines" (2005) 19 WHO Drug Information 236.

World Health Organization Essential Drugs in Brief.

World Health Organization "How to develop and implement a national drug policy" (2003) 4 WHO Policy Perspectives on Medicines 4. 
World Health Organization "Intellectual property rights, innovation and public health: report by the Secretariat" 12 May 2003 (A56/17).

World Health Organization "Selection of Essential Medicines" (2002) 4 WHO Policy Perspectives on Medicines 1.

World Health Organization. Commission on Intellectual Property Rights, Innovation and Public Health Public health, innovation, and intellectual property rights: report of the Commission on Intellectual Property Rights, Innovation and Public Health World Health Organization (2006).

\section{World Intellectual Property Organization documents}

(available at www.wipo.int)

Proposal by Argentina and Brazil for the Establishment of a Development Agenda for WIPO. WIPO Doc WO/GA/31/11, Annex, August 27, 2004. [Argentina-Brazil Development Agenda for WIPO (WO/GA/31/11)]

Proposal to Establish a Development Agenda for WIPO: An Elaboration of Issues Raised in Document WO/GA/31/11 WIPO Doc IIM/1/4. [Group of Friends Elaboration Document IIM/1/4]

WIPO General Assembly Report on the Thirty-Fourth (18 ${ }^{\text {th }}$ Ordinary) Session. Geneva, September 24 to October 3, 2007. (WO/GA/34/16). [WIPO GA WO/GA/34/16]

WIPO Inter-Sessional Intergovernmental Meeting on a Development Agenda for WIPO. First Session, Geneva, April 11 to 13, 2005. Report. (IIM/1/6). [IIM/1/6]

WIPO Provisional Committee on Proposals Related to the WIPO Development Agenda (PCDA). First Session, February 20-24 2006. [PCDA 1/6 Prov 2]

WIPO Provisional Committee on Proposals Related to the WIPO Development Agenda (PCDA). Fourth Session, June 11-15 2007. (PCDA /4/3). [PCDA $4^{\text {th }}$ ]

WIPO Provisional Committee on Proposals Related to the WIPO Development Agenda (PCDA). Fourth Session, June 11-15 2007. (PCDA/4/3. Annex) [PCDA 4 ${ }^{\text {th }}$ Annex].

\section{World Trade Organization and GATT documents}

(available at www.wto.org)

GATT Negotiating Group on Trade-Related Aspects of Intellectual Property Rights, including Trade in Counterfeit Goods. Note of the Secretariat. Meeting of Negotiating Group 12-14 July 1989 [MTN.GNG/NG11/14] 12 September 1989.

GATT Negotiating Group on Trade-Related Aspects of Intellectual Property Rights, including Trade in Counterfeit Goods. Suggestion by the United States for achieving the negotiating objective [MTN.GNG/NG11/W/14] October 1987.

WTO Ministerial Meeting on TRIPS and Public Health. Developing Country Group's submission. (29 June 2001) [IP/C/W/296]. 
WTO Ministerial Meeting on TRIPS and Public Health). Minutes of special discussion on intellectual property and access to medicines. (June 18-22, 2001) [IP/C/M/31]. 